\title{
Biomarkers of Deoxynivalenol Toxicity in Chickens with Special Emphasis on Metabolic and Welfare Parameters
}

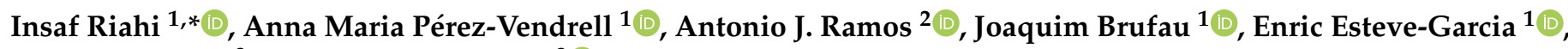 \\ Julie Schulthess ${ }^{3}$ and Virginie Marquis ${ }^{3}$ (i) \\ 1 Animal Nutrition Department, Institute of Agrifood Research and Technology (IRTA Mas Bové), \\ 43120 Constanti, Spain; anna.perez@irta.cat (A.M.P.-V.); joaquim.brufau@irta.cat (J.B.); \\ enric.esteve@irta.cat (E.E.-G.) \\ 2 Applied Mycology Unit, Food Technology Department, University of Lleida, UTPV-XaRTA, Agrotecnio, \\ Av. Rovira Roure 191, 25198 Lleida, Spain; antonio.ramos@udl.cat \\ 3 Phileo by Lesaffre, 137 Rue Gabriel Péri, 59700 Marcq en Baroeul, France; \\ j.schulthess@phileo.lesaffre.com (J.S.); v.marquis@phileo.lesaffre.com (V.M.) \\ * Correspondence: insaf.riahi@irta.cat
}

check for updates

Citation: Riahi, I.; Pérez-Vendrell,

A.M.; Ramos, A.J.; Brufau, J.;

Esteve-Garcia, E.; Schulthess, J.; Marquis, V. Biomarkers of

Deoxynivalenol Toxicity in Chickens with Special Emphasis on Metabolic and Welfare Parameters. Toxins 2021, 13, 217. https://doi.org/10.3390/ toxins13030217

Received: 17 February 2021

Accepted: 14 March 2021

Published: 17 March 2021

Publisher's Note: MDPI stays neutral with regard to jurisdictional claims in published maps and institutional affiliations.

Copyright: (c) 2021 by the authors. Licensee MDPI, Basel, Switzerland. This article is an open access article distributed under the terms and conditions of the Creative Commons Attribution (CC BY) license (https:// creativecommons.org/licenses/by/ $4.0 /)$.

\begin{abstract}
Deoxynivalenol (DON), a trichothecene mycotoxin produced by Fusarium species, is the most widespread mycotoxin in poultry feed worldwide. Long term-exposure from low to moderate DON concentrations can produce alteration in growth performance and impairment of the health status of birds. To evaluate the efficacy of mycotoxin-detoxifying agent alleviating the toxic effects of DON, the most relevant biomarkers of toxicity of DON in chickens should be firstly determined. The specific biomarker of exposure of DON in chickens is DON-3 sulphate found in different biological matrices (plasma and excreta). Regarding the nonspecific biomarkers called also biomarkers of effect, the most relevant ones are the impairment of the productive parameters, the intestinal morphology (reduction of villus height) and the enlargement of the gizzard. Moreover, the biomarkers of effect related to physiology (decrease of blood proteins, triglycerides, hemoglobin, erythrocytes, and lymphocytes and the increase of alanine transaminase (ALT)), immunity (response to common vaccines and release of some proinflammatory cytokines) and welfare status of the birds (such as the increase of Thiobarbituric acid reactive substances (TBARS) and the stress index), has been reported. This review highlights the available information regarding both types of biomarkers of DON toxicity in chickens.
\end{abstract}

Keywords: deoxynivalenol; chickens; deoxynivalenol-3 sulphate; biomarkers

Key Contribution: This is a review reporting the specific and unspecific biomarkers of toxicity of deoxynivalenol mycotoxin in chickens.

\section{Introduction}

The consumption of poultry meat has shown an increase from $2016(116,845.36$ thousand metric ton) to 2018 (120,884.63 thousand metric ton) [1]. Moreover, during the period 2020-2029, global livestock production is expected to expand by $14 \%$, poultry remaining the fastest growing meat accounting for about half of the projected increase in total meat output, while world population is expected to grow only by ca $1 \%$ per year [1].

The goal of the poultry industry is to ensure high productivity without jeopardizing product quality and safety. For this reason, ensuring microbiological and toxicological safety of poultry feed entails a major challenge.

Mycotoxins are fungal metabolites frequently found in feeds that can compromise the health of animals and humans [2]. Besides, mycotoxin feed contamination leads to important economic losses in animal production [3]. Mycotoxins can cause a large range of diseases, as well as death, to both humans and animals [4]. The most important mycotoxins 
associated with poultry health and productivity problems are aflatoxins (AF), fumonisins (FBs), ochratoxin A (OTA), zearalenone (ZEN) and trichothecenes such as deoxynivalenol $(\mathrm{DON})$, and T-2 toxin [5].

As DON is the most frequently encountered mycotoxin in cereal commodities [6], it is not surprising that DON is a major contaminant of poultry feed. A recent large scale survey monitored the occurrence of mycotoxin from 2008 to 2017 in 74,821 samples of finished feed, maize, maize dried distillers grains with soluble (DDGS), maize silage, soybean grains, soybean meal, wheat, barley, and rice collected from 100 countries for the presence of AFB1, DON, ZEN, FBs, OTA, and T-2 [7]. DON was the most prevalent Fusarium mycotoxin followed by FBs and ZEN, mycotoxins were detected in $64 \%, 60 \%$, and $45 \%$ of all samples, respectively [7].

DON is produced predominantly by Fusarium graminearum and Fusarium culmorum and, at to a lesser extent, by Fusarium cerealis and Fusarium pseudograminearum, under conditions of high moisture and low temperature [8]. DON mainly occurs when grains are still in the field, although it can also occur during improper storage [9]. As all trichothecenes, DON contains a tetracyclic sesquiterpenoid 12,13-epoxytrichothecene core, responsible for their cytotoxicity, and a 9, 10 double bonds with various side chain substitutions [10]. Structurally, DON is a polar compound composed of three free hydroxyl groups $(-\mathrm{OH})$ which participate also in its toxicity [11]. DON is a thermostable compound and also is able to resist low $\mathrm{pH}$ levels [12]. DON has been classified by the International Agency for Research on Cancer (IARC) in group 3 as noncarcinogenic to humans [13]. At cellular level, DON is a protein synthesis inhibitor, which induces ribotoxic and oxidative stress [14-16]. Acute DON mycotoxicosis in broiler chickens is rare to occur due to the extremely high feed contamination [8]. Only one study reported the Acute DON mycotoxicosis in broiler chickens which is characterized by extensive ecchymotic hemorrhages, deposition of urates, alteration of the nervous system, and inflammation of the upper gastrointestinal tract [17]. However, the most common mycotoxicosis is due to chronic exposure from low to moderate level of DON and resulted in alteration of the production and health status of the birds which is manifested in alterations of performance, immune, intestinal, physiological, and welfare parameters [18-20].

Susceptibility to DON exposure depends on the affected species [21]. Poultry, for example, are considered resistant to DON mycotoxicosis in comparison with pigs, due to differences on the absorption, distribution, metabolism, and excretion (ADME) process of each species [22]. The guidance level of EU in poultry feed is about $5 \mathrm{mg} / \mathrm{kg}$ while for pigs is only $0.9 \mathrm{mg} / \mathrm{kg}$ [23].

The presence of mycotoxins in food and feed is practically unavoidable due to their stability. Moreover, the simultaneous presence of different mycotoxins in the recent survey is the rule rather than the exception [7]. The simultaneous presence of DON and ZEN, or DON and FBs were the most observed (48\%) in the case of finished feed. It happens in a similar way with corn, with co-occurrences of DON and ZEN in 39\%, and DON and FBs in $49 \%$ of the samples. The most frequent combination in wheat was DON and ZEN, which was detected in $28 \%$ in the samples [7].

Therefore, in order to minimize the risks posed by mycotoxins, the use of feed additives known as mycotoxins detoxifiers seems to be a good strategy to counteract the negative effects induced by mycotoxin, and this is the most common practice used today [24]. In 2019, the feed mycotoxin detoxifiers market was valued at USD 1204.0 million and is expected to grow at a Compound Annual Growth Rate (CAGR) of $6.4 \%$ during the forecast period (2020-2025) [1]. North America and Asia Pacific are the greatest zone using detoxifiers. The market in Asia Pacific is projected to be the fastest-growing, due to large livestock population and their increasing growth rate [25].

The efficacy and safety of these feed additives has been proven through the evaluation of biological biomarkers related to mycotoxin toxicity in a target species [26]. The use of biological biomarkers is highly reliable because they provide a basis for the designing of the in vitro and in vivo trials [26]. In this context, research has been conducted to demonstrate 
the efficacy of detoxifying-agents on unspecific biomarkers such as zootechnical parameters, organ weights, and physiological, immunological, and welfare indicators [27]. However, in the scientific opinion focusing on the experimental design of in vivo studies on the efficacy and safety testing of mycotoxin-detoxifying agents, the European Food Safety Authority (EFSA) has listed several relevant end-points for the different mycotoxins [28]. These end-points, also named biomarkers of exposure, are those directly related to mycotoxin toxicity. For DON, the most relevant end-points proposed are DON itself and its metabolite deepoxy-deoxynivalenol (DOM-1) in blood [28].

This review highlights the biomarkers of exposure and biomarkers of effect of DON in chickens, with special emphasis on metabolic and welfare parameters, in order to identify its impact and therefore facilitate the evaluation of the efficacy of detoxifying-agents. This review may also represent a useful tool for diagnosis of birds in the field.

\section{Biomarkers of Exposure}

Specific well-characterized biomarkers have shown to predict relevant clinical outcomes across a variety of treatments and populations [26]. Up to date, the use of biomarkers has become commonplace, and biomarker-driven research has been proposed as a successful method [29]. The biomarkers of exposure are defined as the metabolites estimated in biological fluids upon the exposure to xenobiotics of individuals [29]. The biomarkers of exposure must be specific for each mycotoxin and target species, and the analytical method used for its detection must be validated for each biological matrix considered [28]. As previously mentioned, EFSA has indicated that the relevant biomarkers directly related to exposure of DON are DON and DOM-1, revealing that de-epoxidation is the most important pathway of metabolization of DON [28]. However, research conducted in different species revealed that the metabolization pathway of DON is species-dependent, and de-epoxidation has shown not to be an important pathway of metabolization for poultry species [30].

The metabolization of DON may be changed if the birds are exposed to DON in a chronic feeding design or to intravenous injection or oral bolus of the synthetic or labeled DON, also by the biological matrices and the sensitivity of the method of analysis used. The most relevant biomarkers of DON exposure in chickens and their methods of determination are reported in Table 1.

After chronic feeding of DON at 7.54 or $9.5 \mathrm{mg} / \mathrm{kg}$ to broiler chickens, DON was quantified as the main metabolite in plasma using LC-MS/MS with limit of quantification (LOQ) $(0.1$ to $1.25 \mathrm{ng} / \mathrm{mL})$ [32,34]. However, the concentration of DON in plasma was under the LOQ $(1.25$ or $23.3 \mathrm{ng} / \mathrm{mL}$ ) when broilers were fed lower (1 or $2.44 \mathrm{mg}$ DON $/ \mathrm{kg}$ feed) or equal to the guidance level of DON in poultry feed (5 mg/ $\mathrm{kg}$ feed) $[31,33,34]$.

On the other hand, DON was the only metabolite detected in the plasma when broilers were exposed to the equivalent to guidance level (approximately $0.5-0.75 \mathrm{mg} / \mathrm{kg} \mathrm{BW}$ ) intravenously or by oral gavage in a two-way cross-over design, using LC-MS/MS with LOQ $(0.1-2.5 \mathrm{ng} / \mathrm{mL})[22,38,39]$. Furthermore, after $2 \mathrm{~h}$ post-administration no DON levels in broilers plasma above LOQ were detected [38]. The study of toxicokinetic parameters upon quantification of DON in plasma revealed a low absolute oral bioavailability (19.3\%) or absorbed fraction $(10.6 \%)$ due to the poor absorption of DON [22,38,39]. This low absorption may be partially related to the rapid transit time in the gastrointestinal tract of birds. The authors suggested also that this poor bioavailability could be associated to the metabolization of DON by the high bacterial content in the gastrointestinal tract of chickens before the main site of absorption [22]. Additionally, it has been reported that the high clearance with the rapid elimination half-life might be the reasons why poultry are relatively tolerant to DON mycotoxicosis [38]. 
Table 1. Biomarkers of exposure of deoxynivalenol (DON) in chickens.

\begin{tabular}{|c|c|c|c|c|c|c|c|}
\hline DON ${ }^{1}$ Dose & Route & Matrix & Metabolites ${ }^{2}$ Analyzed & Analysis ${ }^{3}$ Method & LOQ $(\mathrm{ng} / \mathrm{mL} \text { or } \mathrm{ng} / \mathrm{g})^{4}$ & Main Metabolite & Reference \\
\hline \multicolumn{8}{|c|}{ Acute or chronic administration of DON (farm studies) } \\
\hline $1.5 \mathrm{mg} / \mathrm{kg}$ & Feed & $\begin{array}{c}\text { Plasma, bile, liver and } \\
\text { breast meat }\end{array}$ & $\begin{array}{c}\text { DON } \\
\text { DOM-1 } \\
\end{array}$ & $\begin{array}{l}\text { HPLC with diode } \\
\text { array detection }\end{array}$ & $\begin{array}{c}6.6 \text { (plasma) } \\
13.2 \text { (bile, liver, and breast meat) }\end{array}$ & - & [31] \\
\hline $9.5 \mathrm{mg} / \mathrm{kg}$ & Feed & Plasma & $\begin{array}{l}\text { DON } \\
\text { DOM-1 }\end{array}$ & LC-ESI-MS/MS & $\begin{array}{c}0.1 \text { for DON } \\
0.2 \text { for DOM- } 1\end{array}$ & $\begin{array}{l}\text { DON } \\
\text { DOM-1 }\end{array}$ & [32] \\
\hline 1 or $5 \mathrm{mg} / \mathrm{kg}$ & Feed & $\begin{array}{l}\text { Serum, bile, liver, digesta } \\
\text { of (gizzard, cecum, } \\
\text { rectum), and excreta }\end{array}$ & $\begin{array}{l}\text { DON } \\
\text { DOM-1 }\end{array}$ & HPLC-MS/MS & 23.3 & DON & [33] \\
\hline 2.44 or $7.54 \mathrm{mg} / \mathrm{kg}$ & Feed & Plasma, liver, kidney, bile & $\begin{array}{l}\text { DON } \\
\text { DOM-1 }\end{array}$ & LC-MS/MS & 1.25 & $\begin{array}{l}\text { DON (plasma and bile) } \\
\text { DOM-1 (bile) }\end{array}$ & [34] \\
\hline $2.5 \mathrm{mg} / \mathrm{kg}$ BW & Oral administration & Plasma and organs ${ }^{5}$ & $\begin{array}{c}\text { DON } \\
\text { 10-DON-sulfonate } \\
\text { 10-DOM-sulfonate } \\
\text { DON-3S }\end{array}$ & $\begin{array}{l}\text { Radiotracer method } \\
\text { coupled ( } \gamma \text {-ARC) (radio- } \\
\text { HPLC-IT-TOF-MS/MS) }\end{array}$ & & DON-3S & [35] \\
\hline $1.7 \mathrm{mg} / \mathrm{kg}$ & Feed & Excreta & $\begin{array}{c}\text { DON-3S } \\
\text { DOM-3S } \\
\text { DON, DOM, DON sulfonates } \\
1,2,3 \text {, and DOM sulfonate } 2\end{array}$ & LC-HR-MS/MS & $\begin{array}{c}1 \text { for DON sulfonates } 1,2,3 \\
\text { and DOM sulfonate } 2 \\
4.5 \text { for DON-3S } \\
\text { DOM-3S } \\
\text { DON and DOM }\end{array}$ & DON-3S & [36] \\
\hline $0.5 \mathrm{mg} / \mathrm{kg}$ BW & Single intra-crop bolus & Plasma and excreta & $\begin{array}{c}\text { DON } \\
\text { DON-3S }\end{array}$ & LC-MS/MS and HR-MS & 1 & DON-3S & [37] \\
\hline $0.75 \mathrm{mg} / \mathrm{kg}$ BW & $\begin{array}{l}\text { Intravenous injection or } \\
\text { oral gavage }\end{array}$ & Plasma & $\begin{array}{l}\text { DON } \\
\text { DOM-1 }\end{array}$ & LC-MS/MS & $1-2.5$ & DON & [38] \\
\hline $0.5 \mathrm{mg} / \mathrm{kg}$ BW & $\begin{array}{l}\text { Intravenous injection or } \\
\text { oral gavage }\end{array}$ & Plasma & $\begin{array}{c}\text { DON } \\
3 \text { ADON } \\
15 \text { ADON } \\
\text { DOM-1 }\end{array}$ & LC-MS/MS & $0.1-2$ & DON & {$[22,39]$} \\
\hline $0.75 \mathrm{mg} / \mathrm{kg}$ BW & $\begin{array}{l}\text { Intravenous injection or } \\
\text { oral gavage }\end{array}$ & Plasma & $\begin{array}{c}\text { DON } \\
\text { DOM-1 } \\
\text { DON-3S } \\
\text { DON-3G } \\
\text { 10-DON-sulfonate, DOM-1 and } \\
\text { 10-DOM-1-sulfonate } \\
\end{array}$ & LC-MS/MS & 0.1 & DON-3S & [30] \\
\hline $\begin{array}{l}\text { 0.77 DON-3G mg/kg BW } \\
0.5 \mathrm{DON} \mathrm{mg} / \mathrm{kg} \mathrm{BW}\end{array}$ & $\begin{array}{l}\text { Intravenous injection or } \\
\text { oral gavage }\end{array}$ & Plasma & $\begin{array}{c}\text { DON } \\
\text { DON-3G } \\
\text { DOM-1 }\end{array}$ & LC-MS/MS and HR-MS & 1 & DON-3S & [40] \\
\hline
\end{tabular}

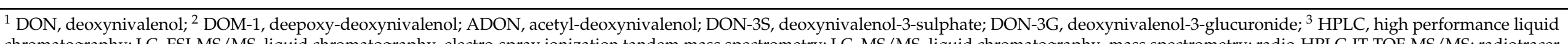

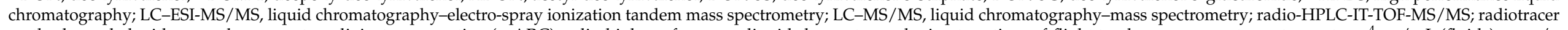

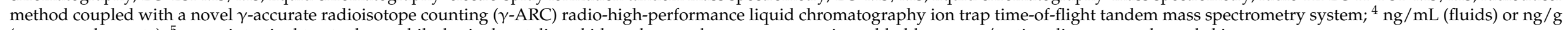
(organs and excreta); ${ }^{5}$ gastrointestinal tract, plasma, bile, brain, heart, liver, kidney, lung, spleen, pancreas, urinary bladder, ovary/testis, adipose, muscle, and skin. 
Awad et al. [33] indicated that after exposure of DON in feed ( 1 or $5 \mathrm{mg} / \mathrm{kg}$ ) to broiler chickens for 35 days, DON concentration was recovered around $10-12 \%$ in gizzard, $18-22 \%$ in cecum and only $6 \%$ in excreta of the DON administered. DON was not detected in liver and bile. Moreover, the DON concentration in the content (digesta) of gizzard, cecum, rectum, and excreta increased in a dose dependent manner. In contrast, DON could not be quantified in bile, liver, breast meat, and kidney [31,34]. The analysis of DON and its metabolites using HPLC in broiler chickens receiving an oral administration of tritium-labelled DON at the dose of $2.5 \mathrm{mg} / \mathrm{kg}$ BW for 5 days, indicated that DON was transiently distributed and rapidly eliminated in all tissues [35]. Low DON concentrations were detected in kidney, liver, heart, lung, spleen, and brain and the higher level was detected in small intestine $6 \mathrm{~h}$ post-administration.

With regard to DOM-1, several studies analyzed this metabolite in plasma, in different organs, or in excreta after chronic DON feeding, intravenous injection or oral gavage using LC-MS/MS [22,30-34,36,38-40]. However, only in very few studies DOM-1 could be quantified [32,34].

All studies mentioned followed the guidelines proposed by EFSA and quantified DON and DOM- 1 as possible metabolites of exposure of DON in different biological matrices of chickens, but they found inconsistent results. The inconsistent results may be partially explained by different levels of 3 and 15 acetyl-DON in the feed. The lack of detection of DOM-1 could be explained by the fact that sulfation occurred so quickly that only DON-3S can be transformed to DOM-3S.

The high-resolution mass spectrometry (HRMS) is a very recent analytical method used to identify or detect the untargeted or novel metabolites, biotransformation products and/or modified fungal metabolites [41]. Since 2014, and with the improvement of the analytical methods it was reported that the most abundant metabolite in case of broiler chickens after receiving DON mycotoxin was a phase II metabolite named DON-3 sulphate (DON-3S) [35]. Still, the formation of DON-3S was observed also in turkeys, pigeons and laying hens $[30,37,42,43]$. Furthermore, in poultry no DON glucuronidation has been observed [30].

DON-3S was identified the first time as a new and major metabolite in poultry in the study of Wan et al. [35]. Among the three new metabolites identified (DON-3S, 10-DONsulfonate, and 10-DOM-1-sulfonate), DON-3S was the major metabolite found in excreta of chickens $(88.6 \%)$ after the oral administration of tritium-labeled DON at the dose of $2.5 \mathrm{mg} / \mathrm{kg}$ BW for 5 days. [35].

Subsequently, Devreese et al. [30], using HRMS analysis of plasma of turkeys and broiler chickens, found that DON-3S was the major metabolite after oral gavage as well as after intravenous injection of $0.75 \mathrm{mg} \mathrm{DON} / \mathrm{kg} \mathrm{BW}$ [30]. Broiler chickens biotransform or metabolize DON more extensively to DON-3S than turkeys [30]. The authors suggested that sulfation mainly occurred in the enterocytes of the intestinal mucosa [36]. Similarly, the analysis by LC-HRMS indicated that DON-3S was mainly present in plasma of broiler chickens dosed at $0.5 \mathrm{mg} \mathrm{DON} / \mathrm{kg}$ BW after intravenous or oral DON administration, respectively; and that DON-3G was not hydrolyzed to DON in this species [40]. The authors concluded that chickens are less sensitive to DON toxicity and explained this relative tolerance by the rapid gastrointestinal transit time or by the extensive and rapid sulfation that occurred.

Schwartz-Zimmermann et al. [36] demonstrated that DON-3S was the best biomarker of exposure in all poultry species. In chickens, for example, biological recovery of DON-3S in excreta reached $80 \%$ after administration of DON $(1.7 \mathrm{mg} / \mathrm{kg}$ feed). These authors indicated that DON is rapidly absorbed from the gastrointestinal tract between crop and jejunum. Then, they suggested that after absorption, DON is extensively biotransformed to DON-3S in the intestinal mucosa, liver and/or kidney. The elimination of DON-3S is rapid and complete into the cloaca via urine by the kidney (via the renal portal vein system in birds), or might be in part be subject to biliary excretion and excreted via feces, or back into the gastrointestinal tract via bile by the liver $[36,43]$. 
It was demonstrated also that the most suitable biomarker for exposure of DON in poultry is DON-3S detected in different biological matrices (plasma and excreta); after a single intra-crop bolus administration of $0.5 \mathrm{mg}$ DON $/ \mathrm{kg}$ BW to broiler chickens aged 21 days and weighed $1 \mathrm{~kg}$, DON-3S was detected and DON was not found. The maximum peak area of DON-3S was achieved in plasma after 30 min post administration and after 3-6 h in dried excreta [37].

In conclusion, DON and DOM-1 are not considered ideal biomarkers in the different biological matrices of chickens. Interestingly, the most abundant metabolite in plasma and excreta of chickens is DON-3S which could be considered the most suitable biomarker of exposure of DON in chickens. This metabolization is a detoxification pathway [44]. On the other hand, the toxicokinetic behavior of DON in chickens was characterized by low absorption, rapid gastrointestinal transit time, transient distribution, high clearance, and rapid elimination. All these factors may explain the low susceptibility of broilers to DON toxicity.

\section{Biomarkers of Effect}

A biomarker of effect is evaluated through a biochemical, physiological, immunological, behavioral, or other organism's alteration [29]. Depending upon the magnitude, the biomarker of effect can be recognized as associated with an established or possible health impairment or disease [29]. Biomarkers of effect are biomarkers indirectly related to mycotoxin toxicity. The biomarkers of effect of DON toxicity in chickens highlighted in this review are productive parameters, organ weights, morphology of small intestine, biochemical and hematological parameters, biomarkers related to immune system (common vaccines response as a part of humoral immune response, cellular immune response, and production of proinflammatory cytokines), and biomarkers related to chicken welfare. To our knowledge, this is the first time that the indicators of toxicity in chickens related to welfare are grouped in a review.

\subsection{Productive Parameters}

Studies about the effects of DON on productive parameters in chickens are listed in Table 2.

The chronic ingestion of DON can cause decrease of feed consumption, body weight gain (BWG) and feed efficiency in chickens [62]. Even at lower concentrations than the recommended guidance value ( $5 \mathrm{mg}$ DON $/ \mathrm{kg}$ feed), the presence of DON in chickens feed might have growth inhibitory effects [54,55,61]. A decreased BWG of broilers fed $1.68 \mathrm{mg}$ DON/kg feed at 21 days has been observed [61]. Slow growing chicks fed $2 \mathrm{mg}$ DON/kg feed had lower BWG [54]. The body weight (BW) and feed intake of broiler chickens have shown to be reduced after feeding $2.5 \mathrm{mg}$ DON/ $\mathrm{kg}$ feed for 35 days [55]. Furthermore, DON exposure from 5 to $14 \mathrm{mg} / \mathrm{kg}$ of feed for 35 days had adverse effects on BW, BWG, feed intake, and feed conversion ratio of chickens $[27,55,56,62]$. Broiler chickens exposed to DON from 15 to $18 \mathrm{mg} / \mathrm{kg}$ feed for 21 days also showed lower performance compared with controls, according to several studies [63-65,69]. Recently, Riahi et al. [19] also reported that the use of DON artificially contaminated feed ( $15 \mathrm{mg} / \mathrm{kg})$ during 42 days reduced the BWG and altered the feed conversion ratio. The poor performance occurring in the presence of DON in feed could be related to the mode of action of this toxin, that is principally the inhibition of protein synthesis at the elongation or termination steps [14].

It was shown also that DON adverse effects on chicken's productive parameters may appear only during specific parts of their growth cycle [51]. 
Table 2. Effects of deoxynivalenol (DON) on productive parameters of chickens.

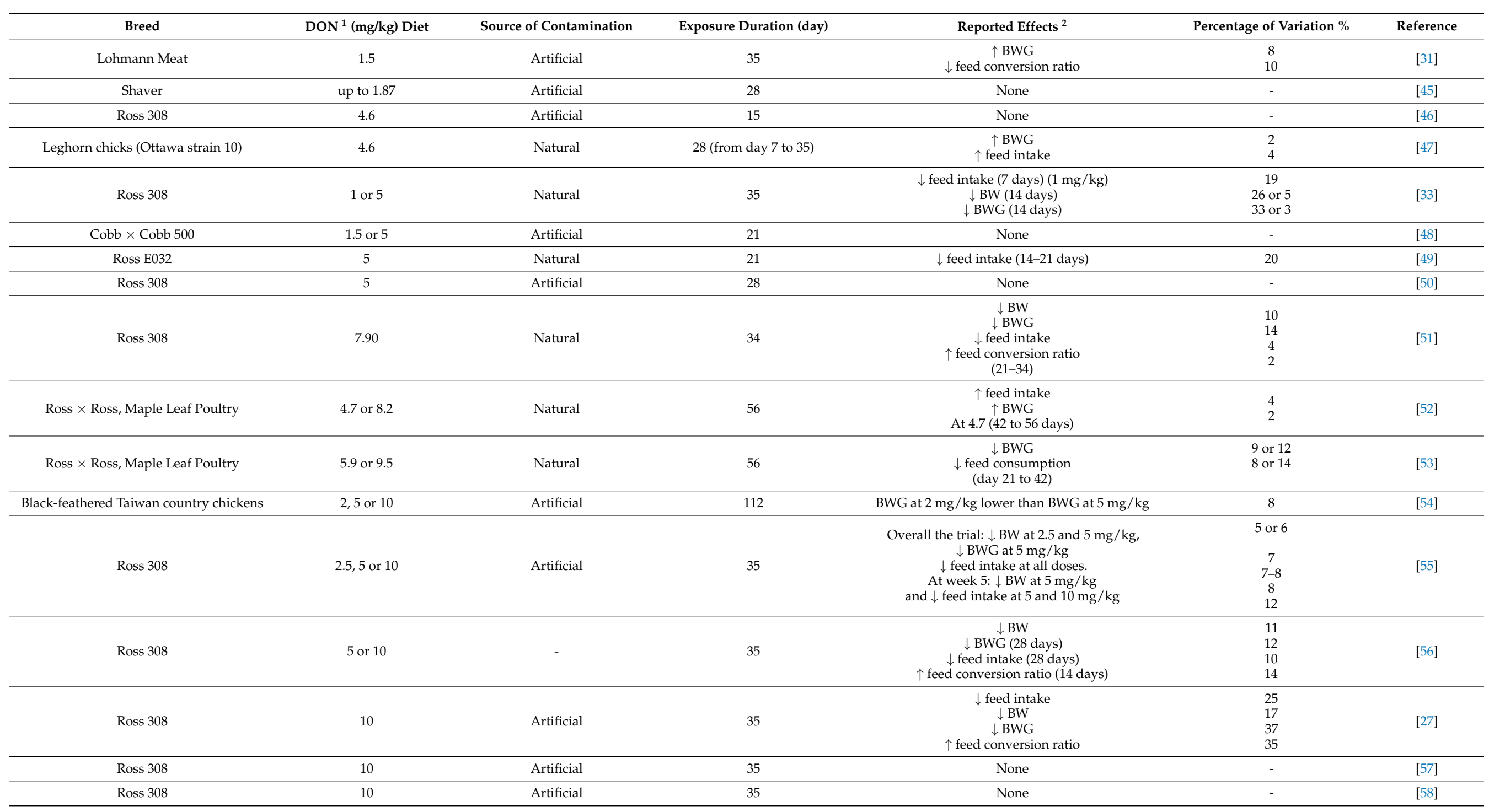


Table 2. Cont.

\begin{tabular}{|c|c|c|c|c|c|c|}
\hline Breed & $\mathrm{DON}^{1}(\mathrm{mg} / \mathrm{kg})$ Diet & Source of Contamination & Exposure Duration (day) & Reported Effects ${ }^{2}$ & Percentage of Variation \% & Reference \\
\hline Ross E032 & 10 & Artificial & 42 & None & - & [59] \\
\hline Ross E032 & 10 & Artificial & 42 & None & - & [60] \\
\hline Ross 308 & 1.68 or 12.20 & Artificial & 35 & $\begin{array}{c}\downarrow \text { feed intake } \\
\downarrow \text { BWG (21 days) }\end{array}$ & $\begin{array}{c}8 \text { or } 13 \\
12 \text { or } 17 \\
\end{array}$ & {$[61]$} \\
\hline Lohmann broilers & Up to 14 & Natural & 35 & $\begin{array}{c}\downarrow \text { feed intake } \\
\downarrow \text { BW } \\
\uparrow \text { in feed to gain ratio }\end{array}$ & $\begin{array}{l}8 \\
4 \\
6 \\
\end{array}$ & {$[62]$} \\
\hline Ross 308 & 5 or 15 & Artificial & 42 & $\begin{array}{c}\downarrow \text { BWG } \\
\uparrow \text { in feed conversion ratio at } 15 \mathrm{mg} / \mathrm{kg}\end{array}$ & $\begin{array}{l}6 \\
7 \\
\end{array}$ & [19] \\
\hline - & 15 & Natural & 21 & $\begin{array}{c}\downarrow \text { BWG } \\
\uparrow \text { in feed conversion ratio } \\
\end{array}$ & $\begin{array}{l}19 \\
28 \\
\end{array}$ & [63] \\
\hline Hubbard $\times$ Hubbard & 16 & Natural & 21 & $\begin{array}{c}\downarrow \text { BWG } \\
\uparrow \text { feed conversion } \\
\end{array}$ & $\begin{array}{l}10 \\
23 \\
\end{array}$ & {$[64]$} \\
\hline Hubbard $\times$ Hubbard & 16 & Natural & 21 & $\begin{array}{c}\downarrow \text { BWG } \\
\uparrow \text { feed conversion }\end{array}$ & $\begin{array}{c}9 \\
20\end{array}$ & [65] \\
\hline Hubbard $\times$ Hubbard & 16 & Natural & 21 & $\begin{array}{c}\downarrow \mathrm{BW} \\
\uparrow \text { feed conversion (day } 8 \text { to } 14)\end{array}$ & $\begin{array}{c}2 \\
24\end{array}$ & [66] \\
\hline- & 16 & Natural & 21 & None & - & [67] \\
\hline Ross 708 & Up to 18 & Natural & 21 & $\begin{array}{c}\downarrow \text { feed intake } \\
\quad \downarrow \text { BWG }\end{array}$ & $\begin{array}{c}8 \\
10\end{array}$ & [69] \\
\hline Leghorn chicks & 18 & Natural & 84 & $\uparrow \mathrm{BW}$ at 28 and 56 days & 5 and 8 & {$[70]$} \\
\hline $\begin{array}{l}\text { White Mountain 6" } \\
\times \text { Hubbard } 9\end{array}$ & Up to 216 & Natural & From 6 to 11 & None & - & [71] \\
\hline
\end{tabular}

${ }^{1}$ DON, deoxynivalenol; ${ }^{2}$ BW, body weight; BWG, body weight gain; $\uparrow$, increase; $\downarrow$, decrease. 
Awad et al. [28] noted that the adverse effect of DON was only pronounced at the beginning of the experiment, but no effect was observed later on BW, BWG, feed consumption, and feed conversion ratio. In fact, they found that feeding DON at 1 or $5 \mathrm{mg} / \mathrm{kg}$ to broiler chickens decreased the feed intake in a quadratic manner during the first week and BW and BWG during the second week [33]. Moreover, a reduction of feed intake was observed only at the third week of the trial after DON (5 mg/kg) exposure to broilers [49]. Adverse DON temporary effect on growth performance was also observed in chickens fed 1.68 or $12.20 \mathrm{mg} \mathrm{DON} / \mathrm{kg}$ feed during the 21 days of exposure, and this effect disappear later [61]. BWG was only reduced during the second week in the study conducted by Kubena et al. [66], which used $16 \mathrm{mg}$ DON/kg of feed during 21 days. The meta-analysis conducted by Andretta et al. [72] reported that the effect of mycotoxins on broiler's growth was greater in young broilers.

It has been hypothesized that the temporal effect produced especially at the early stages of chicken development is related to the capacity of birds to later adapt to DON mycotoxicosis.

In contrast, few studies found that broilers are more sensitive to DON-contaminated diets during later stage of growth. Feeding DON from 5.9 to $9.5 \mathrm{mg} / \mathrm{kg}$ feed to broilers reduced BWG and feed intake during the grower period (21 to 42 days) [53]. Broiler chickens fed $7.90 \mathrm{mg}$ DON/kg feed from 21 to 34 days had lower BW, BWG, feed intake, and altered feed conversion ratio [51]. The authors concluded from this study that after chronic exposure to DON-contaminated diets, the adverse effects on growth performance are not necessarily cumulative [51].

However, other reports indicated that DON at low, moderate, high or extremely high levels had no adverse effects on poultry performance. The exposure to naturally contaminated DON diets, containing 1.5-1.87 $\mathrm{mg}$ DON $/ \mathrm{kg}$ to broiler chickens for 21 or 28 days had no effects on BW, BWG, feed consumption, and feed conversion [45,48]. The absence of effect could be due to a level of DON contamination sharply lower than ones adopted in the previous research $[51,53]$. No adverse effect was indicated on broiler performance feeding the guidance value for $15,21,28$, or $42 \mathrm{~d}$, respectively $[19,46,48,50]$. $\mathrm{BW}, \mathrm{BWG}$, feed intake, and feed conversion ratio were not adversely affected by the inclusion of $10 \mathrm{mg}$ DON $/ \mathrm{kg}$ in broiler diets for 35 or 42 days [57-60]. Productive parameters of birds exposed to $16 \mathrm{mg}$ DON $/ \mathrm{kg}$ feed for 21 days were not adversely affected [67]. Even high level of an artificially DON contaminated diet $(116 \mathrm{mg} / \mathrm{kg})$ did not adversely affect BWG and feed consumption of broiler chickens from 6 to 11 days [71]. Failure to observe significant differences on growth parameters might be suggestive of adaptation of birds to mycotoxins over time, and that poultry are relatively tolerant to DON mycotoxicosis compared with other species, especially pigs, due to the differences in DON absorption, distribution, metabolism, and elimination (ADME) [22].

Furthermore, it has been reported that DON could have growth stimulatory effects. Some studies indicate that DON in poultry feed enhance growth. Feeding $4.6 \mathrm{mg}$ DON $/ \mathrm{kg}$ feed to Leghorn and broiler chicks for 4 weeks (between 7 and 35 days of age) increased their daily BWG [47]. In the same manner, BW of male Leghorn chicks was increased when fed $9 \mathrm{mg}$ DON $/ \mathrm{kg}$ feed at 35 days and $18 \mathrm{mg}$ DON $/ \mathrm{kg}$ feed at 21, 28 and 56 days [68,70].

In addition, the inclusion levels of 4.7 or $8.2 \mathrm{mg}$ DON $/ \mathrm{kg}$ in broiler chickens feed increased BWG and feed intake in a significant quadratic manner in the finisher period [52]. A contaminated diet with DON at $1.5 \mathrm{mg} / \mathrm{kg}$ for 35 days enhanced broiler performance by increasing the BWG and reducing the feed conversion ratio [31]. The enhancement of performance might be the consequence of the increase of nutriments digestibility induced by the presence of the fungus in the grains [62]. Taiwan country chickens exposed to $5 \mathrm{mg} / \mathrm{kg}$ of DON in feed during 16 weeks showed a growth promoting impact in comparison with chickens receiving $2 \mathrm{mg}$ DON $/ \mathrm{kg}$ [54]. It has been suggested that this concentration near to or equal to $5 \mathrm{mg} / \mathrm{kg}$ could have a stimulator and promoting effect on growth of broilers and it was described as an hormesis phenomenon [52], resulting in either a J-shaped or an inverted U-shaped dose response. 
In summary, the adverse effect of DON on broiler performance is the most frequent effect reported among studies. The impairment of BWG, feed intake, and feed conversion ratio could reach up 37,25 and $35 \%$, respectively [27].

The improvement of genetics of broiler chickens over the years could be a factor of consideration of growth effects. In fact, rapidly growing birds may have altered metabolic and nutrient partitioning and has long-been criticized in reducing immunity [73]. Then, rapidly growing birds are more susceptible to detrimental effects of mycotoxins on growth. The effects of DON on productive parameters may depend on the dose and the duration of exposure. The source of mycotoxin used (naturally vs. artificially) is considered also a factor of variation of DON toxicity, in which natural contaminated diets with DON are more frequently toxic than artificially contaminated diets, as reported in Table 2. Moreover, in natural contamination, multi-mycotoxin contamination is very frequent, as most of fungi are able to produce several mycotoxins simultaneously, and feed can be contaminated by several fungi species at the same time. Thus, mycotoxin multicontamination of raw materials is more likely to occur than a single mycotoxin contamination [10,74]. Additionally, the presence of acetylated and glycosylated forms of DON in naturally contaminated feed can increase the global toxicity as these forms are cleaved into DON in digestive tract of animals [75]. In addition, the effects of DON on productive parameters may depend on the climatic factors, the methods of analysis of mycotoxins and the adaptability and the tolerance of chickens to DON mycotoxicosis [5,48]. This tolerance may be due to the biotransformation of DON to DON-3S in chickens, which is much less toxic than DON itself [35].

\subsection{Relative Weight of Organs}

The effect of DON on organ weights of chickens is summarized in Table 3.

Regarding DON toxicity, this biomarker is highly variable and results are contradictory. The weight of organs expressed as a percentage of the body weight of the bird is named relative weight (RW). Some organs seemed to be the most affected in different studies as, for example, organs with high turnover of protein such as liver, immune organs and small intestine [14]. The RW of liver decreased in birds fed $18 \mathrm{mg}$ DON $/ \mathrm{kg}$ feed during 5 weeks [68], but this parameter remained unaltered using the same dose of toxin during 12 weeks, and this may be explained by the difference in the duration of exposure [70]. Indeed, the time of toxin exposure may be a significant factor as the organ initially swells with toxin exposure followed by shrinkage [53]. Similarly, in broiler chickens exposed to DON at different levels (up to $10 \mathrm{mg} / \mathrm{kg}$ ), a significant decrease of liver RW is observed at week 3 of the trial [55]. However, in another trial, this parameter increased temporally in the second week of exposure for broilers fed a low DON diet (1.68 mg DON $/ \mathrm{kg}$ ) [61]. The changes observed on the RW of the liver might be associated to lipid metabolism alterations [63].

It has been previously observed that $10 \mathrm{mg}$ of $\mathrm{DON} / \mathrm{kg}$ diet for 35 days decreased the RW of kidneys of broiler chickens and it has been suggested that DON alter the indicated organ cells [76]. In contrast, other reports indicated that the RW of kidneys remained unaltered $[62,65,68,70]$.

The RW of gizzard increased in several studies after DON exposure of broiler chickens $[19,64,65,68,70,76]$. The increase of RW of gizzard might be directly related to a difference in the density of the diets or might be a result of the irritation of the upper gastrointestinal tract [68].

The RW of small intestine of broilers fed $5 \mathrm{mg} / \mathrm{kg}$ DON for 21 days decreased [49]. In the same manner, Yunus et al. [77] reported a reduction in the RW of duodenum and jejunum, and they suggested that this decrease could be due to the reduction of villus height which then resulted in decreased digestion of nutrients and energy. 
Table 3. Effects of deoxynivalenol (DON) on relative organ of weights of chickens.

\begin{tabular}{|c|c|c|c|}
\hline $\mathrm{DON}^{1}(\mathrm{mg} / \mathrm{kg})$ Diet & Exposure Duration (d) & Reported Effects ${ }^{2}$ & Reference \\
\hline Up to 1.87 & 28 & $\begin{array}{l}\text { No effect on crop, proventriculus, gizzard, intestines, heart, liver, } \\
\text { pancreas, kidneys, testes, adrenals, and thyroids }\end{array}$ & [45] \\
\hline 1 or 5 & 35 & $\begin{array}{l}\text { No effect on RW of heart, proventriculus, gizzard, pancreas, liver, small } \\
\text { intestine, cecum, colon, thymus, spleen and bursa of Fabricius }\end{array}$ & {$[33]$} \\
\hline 5 & 21 & $\begin{aligned} \downarrow R W \text { of small intestine, } & =\text { RW of heart, gizzard, pancreas, caecum, } \\
& \text { colon, and spleen }\end{aligned}$ & {$[49]$} \\
\hline 5.9 or 9.5 & 56 & No effect on RW of liver, kidney, spleen, and bursa of Fabricius & [53] \\
\hline 2,5 or 10 & 112 & $\uparrow \mathrm{RW}$ of spleen (at $5 \mathrm{mg} / \mathrm{kg}$ ) & [54] \\
\hline $2.5,5$ or 10 & 35 & $\downarrow$ RW of liver & [55] \\
\hline 10 & 35 & No effect on RW of bursa of Fabricius, spleen, and thymus & [27] \\
\hline 10 & 35 & $\begin{array}{c}\uparrow \mathrm{RW} \text { of gizzard, } \downarrow \text { RW of kidneys, = RW of brain, heart, pancreas, liver, } \\
\text { lung, thymus, spleen, and bursa of Fabricius }\end{array}$ & [76] \\
\hline 1.68 or 12.20 & 35 & $\uparrow \mathrm{RW}$ of liver and spleen, = RW of heart and thymus & [61] \\
\hline 1.68 or 12.20 & 35 & $\downarrow$ RW of duodenum and jejunum, = RW of proventriculus and gizzard & [77] \\
\hline Up to 14 & 35 & $\begin{array}{c}\uparrow \mathrm{RW} \text { of heart, } \downarrow \text { RW of spleen, }=\mathrm{RW} \text { of proventriculus, gizzard, liver, } \\
\text { kidneys, small intestine, and bursa of Fabricius }\end{array}$ & {$[62]$} \\
\hline 5 or 15 & 42 & $\begin{array}{c}\uparrow \mathrm{RW} \text { of gizzard and thymus, } \downarrow \text { RW of colon and small intestine, }=\mathrm{RW} \\
\text { of heart, proventriculus, pancreas, liver, kidneys, cecum, spleen and } \\
\text { bursa of Fabricius }\end{array}$ & {$[19]$} \\
\hline 15 & 21 & $\begin{array}{c}\uparrow \mathrm{RW} \text { of gizzard, heart and bursa of Fabricius, }=\mathrm{RW} \text { of proventriuclus, } \\
\text { liver and kidney }\end{array}$ & {$[63]$} \\
\hline 16 & 21 & $\uparrow \mathrm{RW}$ of gizzard, = RW of proventriculus, spleen, liver, and kidney & {$[64]$} \\
\hline 16 & 21 & $\begin{array}{c}\uparrow \mathrm{RW} \text { of gizzard, }=\mathrm{RW} \text { of proventriuclus, liver, kidneys, spleen, and } \\
\text { bursa of Fabricius }\end{array}$ & {$[65]$} \\
\hline 16 & 21 & $\begin{array}{l}\uparrow \mathrm{RW} \text { of gizzard and bursa of Fabricius, }=\mathrm{RW} \text { of proventriculus, } \\
\text { pancreas, liver, kidneys, and spleen }\end{array}$ & {$[66]$} \\
\hline 16 & 21 & $\begin{array}{l}\text { No effect on RW of liver, left kidney, heart, spleen, pancreas, } \\
\text { proventriculus, gizzard, and bursa of Fabricius }\end{array}$ & {$[67]$} \\
\hline 9 or 18 & 35 & $\begin{array}{c}\downarrow R W \text { of liver, = RW kidney, heart, proventriculus, testes, spleen, bursa } \\
\text { of Fabricius, and } \uparrow \text { RW of gizzard }\end{array}$ & {$[68]$} \\
\hline 18 & 84 & $\begin{array}{c}\uparrow \mathrm{RW} \text { of gizzard, = RW liver, kidney, heart, proventriculus, spleen, } \\
\text { bursa of Fabricius, and testes }\end{array}$ & [70] \\
\hline
\end{tabular}

${ }^{1}$ DON, deoxynivalenol; ${ }^{2} \mathrm{RW}$, relative weight; $\uparrow$, increase; $\downarrow$, decrease; =, unaffected.

Regarding the immune organs, different results have been reported using the same DON concentration during the same exposure time; the RW of bursa of Fabricius of birds did not change after feeding $16 \mathrm{mg}$ DON $/ \mathrm{kg}$ of feed for 21 days [65] and, using the same trial conditions, an increase of the RW of bursa of Fabricius was found [66]. Results of these studies are highly variable, suggesting that organ weights might not be a good indicator of DON toxicity [78]. An increase of the RW of spleen for broilers fed a low level of DON $(1.68 \mathrm{mg} / \mathrm{kg})$ at week 4 was reported [61]. Similarly, the RW of spleen was higher in the chickens fed $5 \mathrm{mg} / \mathrm{kg}$ of DON contaminated diet and this increase was interpreted as a consequence of the irritation of chicken's immune system by the toxin, the swelling of this organ and some alterations on a cellular level [54]. Nevertheless, the indicated immune organ was reduced in Lohman chickens fed up $14 \mathrm{mg}$ DON $/ \mathrm{kg}$ for 5 weeks [62]. In other studies, the RW of spleen was not affected by DON chickens' diets $[19,33,49,53,60,65,68,70,76]$. In our recent study, a significant increase of thymus of birds exposed to DON at 5 or $15 \mathrm{mg} / \mathrm{kg}$ for 42 days was reported [19].

Due to the contradiction between results, it can be considered that RW of organs might not be a very precise biomarker of DON toxicity in birds. However, based on the frequencies of effects of DON on RW of organs, the RW of gizzard being the one the most impacted by DON, it can be considered as a promising biomarker. 


\subsection{Intestinal Morphology}

As all trichothecenes, DON is a small molecule that has the capacity to passively cross through cell membranes and to be easily absorbed by the epithelium cells of the intestine. These epithelium cells can be exposed to high concentrations of DON following ingestion of contaminated diets [21]. On the other hand, the intestinal tract is a very important barrier to ingested feed contaminants and is also the first line of defense against various gut antigens [79]. Moreover, it has been reported that DON alter intestinal morphology [33]. The studies reporting the impairment of intestinal morphology parameters in chickens are listed in Table 4.

Table 4. Effects of deoxynivalenol (DON) on morphological parameters of small intestine of chickens.

\begin{tabular}{|c|c|c|c|}
\hline $\mathrm{DON}^{1}(\mathrm{mg} / \mathrm{kg})$ Diet & Exposure Duration (Days) & Reported Effects & Reference \\
\hline 1 or 5 & 35 & $\begin{array}{l}\downarrow \text { villus height of jejunum } \\
\quad \downarrow \text { villus surface area }\end{array}$ & [33] \\
\hline 2.88 to 4.38 & 23 & $\downarrow$ villus height of duodenum & [80] \\
\hline 5 & 21 & $\downarrow$ height and width of villi in duodenum & [49] \\
\hline 5 & 28 & $\downarrow$ villus height and villus height to crypt depth ratio in the duodenum & [50] \\
\hline 7.54 & 21 & $\downarrow$ villus height and crypt depth in the duodenum and jejunum & [81] \\
\hline 6.62 to 7.90 & 21 & $\begin{array}{l}\downarrow \text { density of small intestine, } \downarrow \text { villus height in the jejunum, } \downarrow \text { villus height, } \\
\text { and crypt depth in the ileum }\end{array}$ & [51] \\
\hline 2,5, or 10 & 112 & $=$ villus height of jejunum and ileum & [54] \\
\hline 10 & 21 & $\begin{array}{c}\downarrow \text { villus height, } \uparrow \text { crypt depth, } \downarrow \text { villus height to crypt depth ratio in } \\
\text { the duodenum }\end{array}$ & [82] \\
\hline 10 & 35 & $=$ length and density of different segments of gastrointestinal tract & [58] \\
\hline 10 & 42 & $\downarrow$ villus height of jejunum, = crypt depth and villus height and crypt depth & [83] \\
\hline 10 & 42 & $\downarrow$ villus height in the duodenum and jejunum & [60] \\
\hline 1.68 or 12.20 & 35 & $\begin{array}{l}\downarrow \text { villus height, } \uparrow \text { length } \\
\text { of duodenum and jejunum }\end{array}$ & [77] \\
\hline 5 or 15 & 42 & $\uparrow$ length and $\downarrow$ density of small intestine, $=$ villus height and crypt depth & [19] \\
\hline Up to 18 & 21 & $\begin{array}{l}\text { } \uparrow \text { villus height in the mid-ileum } \\
\text { No effects on crypt depth and goblet cells per villi counts }\end{array}$ & [69] \\
\hline
\end{tabular}

${ }^{1}$ DON, deoxynivalenol; $\uparrow$, increase; $\downarrow$, decrease; =, unaffected.

The density of the intestine was identified as the ratio between the absolute weight of small intestine and its length. Birds fed DON-contaminated diets from 1 to 21 days had lower intestinal density [51]. In broilers exposed to 1.68 or $12.20 \mathrm{mg} / \mathrm{kg}$ for 35 days, DON exposure has shown to produce a reduction of the weights of duodenum and jejunum and an increase of length of both segments and, consequently, DON decreased the small intestine density, in a dose- and time-dependent manner [77]. Additionally, the length was lower, and the density of the small intestine was higher in broilers receiving 5 and $15 \mathrm{mg}$ DON/kg compared with controls [19]. Contaminated DON feed at concentration $3-4 \mathrm{mg} / \mathrm{kg}$, which is below the European maximum guidance level, resulted in a decreased duodenal villus height [80]. Jejunal and ileum histological analysis revealed that broiler chickens exposed to the DON diets for 34 days had shorter villi and reduced crypt depth than control birds [51]. Additionally, it has been shown that chickens consuming DON (5 or $10 \mathrm{mg} / \mathrm{kg}$ feed) had shorter and thinner villi compared to chickens ingesting control diets $[49,60,82,83]$. It has been also reported a significant reduction of villus height, villus surface area and muscularis thickness in jejunum of broiler chickens upon feeding naturally contaminated diets with DON (1 or $5 \mathrm{mg} / \mathrm{kg}$ feed) [33]. Data reported by Yunus et al. [77] indicated that feeding $12.20 \mathrm{mg} / \mathrm{kg}$ of DON contaminated diet to broiler chickens resulted in a reduced villus height in the duodenum and jejunum. Similarly, feeding DON contaminated feed $(7.54 \mathrm{mg} / \mathrm{kg})$ for 21 days decreased the villus height and crypt depth both in duodenum and jejunum of broiler chickens [81]. In the same manner, villus height and 
villus height to crypt depth ratio in the duodenum were decreased in chickens receiving the guidance value for 4 weeks [50]. Only one study shows opposite results regarding the intestine morphology, as they observed that feeding diets at a concentration up to $18 \mathrm{mg}$ of $\mathrm{DON} / \mathrm{kg}$ of feed linearly increased broiler villi heights [69]. In recent reports villus height was unaffected by the dietary inclusion of DON $[19,54]$.

Decrease of villus height may be due to villus contraction and leads to the impairment of nutrient transport and utilization, resulting in alteration of gain weight of animals fed DON [84]. Furthermore, Robert et al. [85] indicated that the shortening of villus height produced by DON may be explained by the implication of this mycotoxin in the balance between epithelial cell proliferation and apoptosis. As such, the adverse effect of DON on the villus height can be linked with an impaired nutrient digestion due to a reduced number of differentiated epithelial cells [86].

After a mechanical or toxic damage, more enterocytes need to be generated to migrate progressively along the villus toward the tip which induced the change in crypt depth [87]. In addition, change in crypt depth in birds fed DON could be attributed to the capacity of DON to reduce cell proliferation [81]. The crypt-depth to villus-height ratio was calculated to assess the intestinal architectural changes after the treatment [87].

Changes observed in morphology and histology of small intestine could be due to the irritant effects of DON on the upper gastrointestinal tract and the inhibition of protein biosynthesis, leading to the alteration of the absorption and digestion mechanisms which negatively affect bird growth $[79,81]$.

To conclude, we could consider that the decrease of villus height is the most frequent effect reported among studies. This biomarker could be useful in the research on developing and efficacy proving of mycotoxin-detoxifying agents. Moreover, research is now growing in the field of gut health and focusing on the effects of mycotoxins in the gastro-intestinal tract (GIT).

\subsection{Biochemical and Hematological Parameters}

Biochemical and hematological parameters are used to infer the health status of animals. The most significant results of the effect of DON on biochemical blood parameters are indicated in Table 5.

Table 5. Effects of deoxynivalenol (DON) on blood biochemistry and hematology of chickens.

\begin{tabular}{|c|c|c|c|}
\hline $\mathrm{DON}^{1}(\mathrm{mg} / \mathrm{kg})$ Diet & Exposure Duration (Days) & Reported Effects ${ }^{2}$ & Reference \\
\hline 2.95 & 28 & $\downarrow$ levels of Tot Prot, Alb $\uparrow$ ALT, AST and ALP. & [88] \\
\hline 3 & 42 & $\downarrow$ levels of Tot Prot, mg, Trig and free glycerol, $\uparrow$ ALT activity & [89] \\
\hline 3 & 42 & $\downarrow$ Tot Prot, Trig and free glycerol, $\uparrow$ ALT activity & [90] \\
\hline 4.7 or 8.2 & 56 & $\begin{array}{c}\text { Quadratic responses in serum concentrations of Alb and } \gamma \text {-GT, } \downarrow \text { lipase } \\
\text { activity, } \uparrow \mathrm{UA} \text {, hemoglobinemia and erythrocytosis }\end{array}$ & [52] \\
\hline 10 & 35 & $\downarrow$ of plasma Tot Prot and UA, $\downarrow$ plasma Trig level (tendency), & [27] \\
\hline 10 & 35 & $\downarrow$ level of ALT, $\uparrow$ serum Chol and Trig & [58] \\
\hline Up to 14 & 35 & $=$ Glu, Tot Prot, Hct and Hgb & [62] \\
\hline 5 or 15 & 42 & $\downarrow$ CK (at $5 \mathrm{mg} / \mathrm{kg}$ ) and $\downarrow$ level of Chol (at $15 \mathrm{mg} / \mathrm{kg}$ ) & [19] \\
\hline 5 or 15 & 42 & $\downarrow$ Hgb (dose-dependent), $\downarrow$ erythrocytes (at $15 \mathrm{mg} / \mathrm{kg}$ ) & [91] \\
\hline 15 & 21 & $\uparrow$ activities of AST, LDH and $\gamma-$ GT. & [63] \\
\hline 16 & 21 & $\downarrow$ Trig, alterations in blood erythrocyte count, Hgb and Hct & [64] \\
\hline 16 & 21 & $\downarrow$ Glu level & [65] \\
\hline 16 & 21 & No effect on Glu, ALT, AST, Creat and Hgb & [67] \\
\hline 9 or 18 & 35 & $\begin{array}{c}\downarrow \text { Glu, Trig and LDH, } \uparrow \text { Creat, } \\
\qquad \text { in } \mathrm{Hgb} \text { and Hct }\end{array}$ & [68] \\
\hline 18 & 63 & $\downarrow$ Hgb concentration, erythrocyte count and Hct & [92] \\
\hline 18 & 84 & $\downarrow$ in Hgb concentration at 28 days & [70] \\
\hline 50 & 21 & No effect on hematological parameters & [92] \\
\hline
\end{tabular}

${ }^{1}$ DON, deoxynivalenol; ${ }^{2}$ Tot Prot, total protein; Alb, albumin; UA, uric acid; Chol, cholesterol; Trig, triglycerides; ALT, alanine transaminase; AST, aspartate transaminase; ALP, alkaline phosphatase; $\gamma$-GT, gamma-glutamyl transferase; LDH, lactate dehydrogenase; Glu, glucose; Creat, creatinine; $\mathrm{CK}$, creatine kinase; Hgb, hemoglobin; Hct, hematocrit; $\mathrm{MCHC}$, mean corpuscular hemoglobin concentration; $\uparrow$, increase; $\downarrow$, decrease; $=$, unaffected. 
Dietary DON may affect the enzymes reflecting liver and kidney activities such as lactate dehydrogenase (LDH), alanine aminotransferase or transaminase (ALT), aspartate transaminase (AST), alkaline phosphatase (ALP), gamma-glutamyl transferase $(\gamma$-GT), creatine kinase (CK), and creatinine. Broilers exposed to $15 \mathrm{mg} D O N / \mathrm{kg}$ feed during 21 days had higher AST activity in blood [63]. However, the same dietary level in chickens feeding during 42 days did not affect this enzymatic activity [19]. ALP and AST activities increased in broilers exposed to $2.95 \mathrm{mg}$ DON $/ \mathrm{kg}$ feed for the second last week of the trial [88]. Faixová et al. [89,90] showed an elevation of serum ALT activity in broilers exposed to $3 \mathrm{mg}$ DON $/ \mathrm{kg}$ feed for 6 weeks. However, broilers fed DON $(10 \mathrm{mg} / \mathrm{kg})$ for 35 days had lower ALT [58]. Swamy et al. [52] reported that DON at $4.6 \mathrm{mg} / \mathrm{kg}$ increased the levels of $\gamma$-GT activity. These results were in accordance with a previous report of chickens fed $15 \mathrm{mg}$ DON $/ \mathrm{kg}$ [63]. Contaminated diet with DON at $5 \mathrm{mg} / \mathrm{kg}$ decreased the serum creatine kinase level in broiler chickens aged 42 days [19], reflecting the reduction of this enzyme from the circulation [93]. Generally, the changes obtained in enzymatic activities might be due to hepatic disorders, chronic liver damage, leakage of the enzymes into the blood, biliary obstruction, or kidney affliction $[52,58,88]$.

For biochemical parameters reflecting lipid metabolism, higher cholesterol level and triglycerides were observed in broilers fed DON at $10 \mathrm{mg} / \mathrm{kg}$ for 35 days [58]. The increased cholesterol level may suggest liver or kidney damage function and a high stress status of the bird [58]. The increased level of triglycerides might be related to lipid metabolism alteration and or to biliary obstruction [58]. These results are in contrast with the previous and actual findings which observed decreased cholesterol and triglycerides levels in broilers $[19,27,64,68,89,90]$. This is in agreement with the meta-analysis report of Andretta et al. [94] indicating that broilers fed challenged mycotoxins (T2, FBs, DON, OTA, and ZEN) had lower total cholesterol $(-14 \%)$ and lower triglycerides $(-39 \%)$ compared to negative control birds. It was suggested that these changes in indicated biochemical parameters could be explained by involvement of liver and a shift of concentrations from the blood to the liver [95].

Regarding biochemical parameters reflecting protein metabolism, it has been described that the total plasma protein and albumin levels of chickens fed a contaminated diet with $2.95 \mathrm{mg} \mathrm{DON} / \mathrm{kg}$ feed during 2 weeks of exposure were decreased compared to control [88]. The reduction of total protein level after feeding DON to broilers was observed also in previous reports $[27,89,90]$. This decrease could be the result of protein and DNA synthesis inhibition induced by DON [14]. Additionally, the decreased plasma protein level may be related to the decrease of feed intake. DON toxicity is expressed also through a change in the profile of uric acid (UA) [27,52]. The decreased level of UA may be attributed to the efficiency of amino acid utilization, changes in enzyme systems, altered renal filtration, and reabsorption rates [95].

Blood hematological parameters serve as indicators of the physiological state of birds [96], but very limited information is available regarding the effect of DON exposure on hematological variables in poultry. The absence of significant effect of DON exposure on hematology of broiler chickens exposed to different DON concentrations (up to $16 \mathrm{mg} / \mathrm{kg}$ feed) at 21 or 35 days has been shown [62,67]. Even $50 \mathrm{mg} / \mathrm{kg}$ of DON did not change these indicators in broiler chickens aged 21 days [92]. In other studies, a significant decrease in hemoglobin concentration was observed accompanied or not with a decrease on hematocrit and a decrease on erythrocytes count of birds exposed to DON mycotoxin $[52,64,65,70,91$, 92]. In their meta-analysis, Andretta et al. [94] reported that the presence of mycotoxins in broiler diets decreased the hematocrit and the hemoglobin concentration by $5 \%$ and $15 \%$, respectively. The decreasing of hematocrit hypothesized that hematopoietic tissue may be affected by DON toxin [97]. However, no hemorrhage or hemolysis was observed in broilers. The decrease of hemoglobin and erythrocytes does not necessarily mean that DON induces anemia in poultry, because values are within the range of reference [96]. Moreover, the decrease of hemoglobin and erythrocytes is a marker of immune system alteration. 
The most frequent effect of DON in blood biochemistry and hematology of chickens among studies was the decrease of blood protein, triglycerides, hemoglobin, and erythrocytes and the increase of ALT. These indicators could be useful to evaluate the DON effect on the physiological and hemostatic state of chickens. However, it should be noted that blood biochemical and hematological parameters were slightly affected by DON contaminated feed, as these parameters were still within their physiological reference range [98-100], and therefore, of limited physiological relevance.

\subsection{Biomarkers Related to Immune System}

Few studies have been conducted regarding DON effects on poultry immune system, despite that the first outcome of DON toxicity is immune system functions and responses. As the immune system has rapidly proliferating cells and tissues with high rates of protein turnover, it is consequently considered the most susceptible system to DON and trichothecenes mycotoxicosis [14]. Responses to common vaccines as Newcastle disease virus (NDV) and infectious bronquitis virus (IBV) are considered as humoral immune response parameters [27,62]. Leukocytes apoptosis and lymphocytes proliferation are considered as cellular immune responses to DON detrimental effects [27,101]. Furthermore, the production of proinflammatory cytokines could be used as an indicator to evaluate the effects of DON contaminated diets exposure on immune system competence or modulation [102]. The effect of DON on immune system functions and responses through the evaluation of those indicators mentioned above are reviewed in Table 6.

Table 6. Effects of deoxynivalenol (DON) on immune biomarkers of chickens.

\begin{tabular}{|c|c|c|c|}
\hline $\mathrm{DON}^{1}(\mathrm{mg} / \mathrm{kg})$ Diet & Exposure Duration (Days) & Reported Effects ${ }^{2}$ & Reference \\
\hline 1.6 & 34 & $\downarrow$ IL- $6,=$ IFN- $\gamma$, IL-1 $\beta$, IL-17, and IL-10 in cecal tonsils & [103] \\
\hline 2 & 42 & $\begin{array}{c}\downarrow \text { NDV titers at } 28 \text { days and } 42 \text { days, } \uparrow \text { mRNA expression of IL-1ß and IL-6, } \\
\downarrow \text { mRNA expression of IFN- } \gamma \text { in spleen }\end{array}$ & [104] \\
\hline Up to 3.8 & 70 & $\uparrow$ IFN- $\gamma$ gene expression in cecal tonsils & [105] \\
\hline Up to 5 & 35 & $\begin{array}{c}\uparrow \text { mRNA expression of IL- } 6 \text { in the duodenum, } \downarrow \text { mRNA expression of IL-8 } \\
\text { and IL-10 in the jejunum (quadratic trend) }\end{array}$ & [102] \\
\hline 5 & 28 & No effect on LITAF and IL-1 $\beta$ in spleen and bursa of Fabricius tissues & [50] \\
\hline 4.7 or 8.2 & 56 & $=\mathrm{IBV}$ & [52] \\
\hline 5.9 or 9.5 & 56 & $\downarrow \mathrm{B}$ cells and T cells & [53] \\
\hline 2,5 or 10 & 112 & Apoptosis in chicken spleen lymphocytes & [54] \\
\hline 10 & 35 & $\downarrow \downarrow$ of lymphocytes and $\downarrow$ IBV & [27] \\
\hline 10 & 35 & $\begin{array}{c}\text { In plasma: } \downarrow \text { LITAF, }=\text { IL- } 8, \text { in jejunum: } \downarrow \text { IL-1 } \beta, \text { IFN- } \gamma, \text { TGFBR1, }=\text { LITAF, } \\
\text { IL- } 8 \text { and NF-kB1 }\end{array}$ & [106] \\
\hline 10 & 35 & $\downarrow$ IBV titers & [58] \\
\hline 12.2 & 35 & $\uparrow$ NDV (14 days / 28 days), $\downarrow$ IBV (35 days) & [61] \\
\hline 3.5 to 14 & 35 & $\downarrow$ NDV titers & [62] \\
\hline 5 or 15 & 42 & $\begin{array}{c}=\mathrm{NDV} \text { and IBV }, \uparrow \text { plasma IL- } 8, \uparrow \text { the mRNA of IL- } 6, \text { IFN- } \gamma \text { and IL- } 1 \beta \text { in } \\
\text { jejunum tissues (at } 5 \mathrm{mg} / \mathrm{kg} \text { ) }\end{array}$ & [91] \\
\hline 18 & 63 & No effect on NDV & [92] \\
\hline 18 & 126 & $\downarrow$ NDV & [92] \\
\hline
\end{tabular}

${ }^{1} \mathrm{DON}$, deoxynivalenol; ${ }^{2} \mathrm{NDV}$, Newcastle disease virus; IBV, infectious bronquitis virus; IFN- $\gamma$, interferon gamma; IL-1 $\beta$, interleukin 1- $\beta$; IL-6, interleukin 6; LITAF, lipopolysaccharide-induced TNF- $\alpha$ factor, TGFBR1, transforming growth factor beta receptor I; NF- $k \beta$, nuclear factor kappa $\beta$; CCK-8, cell counting kit-8; IL-10, interleukin 10, IL-17, interleukin 17; $\uparrow$, increase; $\downarrow$, decrease; =, unaffected.

\subsubsection{Biomarkers Related to Humoral Immune Response}

Dänicke et al. [62] suggested that the antibody titers against NDV could be a relevant biomarker for DON effects on protein synthesis inhibition due to the reduction of antibody titers to NDV when broiler chickens fed up $14 \mathrm{mg}$ of DON/ $\mathrm{kg}$ feed for 5 weeks. In the same manner, broilers exposed to a mixture of Fusarium mycotoxins, included DON, presented a decreased NDV titers at 28 and 42 days of age [104]. Additionally, NDV antibody titers decreased in White Leghorn chicks fed $18 \mathrm{mg}$ of DON/ $\mathrm{kg}$ of feed at 18 weeks [92]. However, the exposure to $12.2 \mathrm{mg}$ of DON/ $\mathrm{kg}$ of feed of broilers for 5 weeks increased titers against NDV at week 2 and week 4 but decreased numerically at week 5 [61]. As trichothecenes, DON is both immunostimulatory and immunosuppressive, depending on the level and the length of exposure [101]. The enhancement or the depression of the response to NDV 
observed may be due to the ability of DON to modulate the immune response during chronic exposure. Concerning the antibody titers against IBV, it was concluded that it is also a good indicator of depression of protein synthesis induced by the exposure of DON [27]. Antibody titers to IBV decreased in broiler chickens receiving DON at 10, 12.2, or $12.6 \mathrm{mg} / \mathrm{kg}$ for 5 weeks $[27,61]$. Meanwhile, no effect on the IBV titers was found following exposure of broiler chickens to different concentrations of DON $(4.7,8.2$, or $9.7 \mathrm{mg} / \mathrm{kg}$ of feed) for 21 and 42 days [52]. Furthermore, no effects of a concentration of $12.2 \mathrm{mg} \mathrm{DON} / \mathrm{kg}$ were found on antibody against IBV titers in broiler chickens after 14 and 28 days [61].

The discrepancies in results of these biomarkers of effect might indicate that the humoral immune response of broilers fed DON is variable, and further studies should be undertaken [61]. It might be interesting for these studies to take into account parent breeder vaccination schedule and chick maternal antibody levels.

\subsubsection{Biomarkers Related to Cellular Immune Response}

The first molecular target of DON and other trichothecenes is the ribosome. DON inhibits protein synthesis via binding to the peptidyl transferase region of the 605 subunit of the ribosome and interfering with the elongation step [107]. Ribosome binding leads first to the activation of ribosomal-associated protein kinase $\mathrm{R}(\mathrm{PKR})$ and tyrosine protein kinase (Hck) and, subsequently, the activation of mitogen activated protein kinases (MAPKs) signaling, including p38, Jun N-terminal kinase (JNK) and extracellular signal-regulated kinase 1 and 2 (ERK1/2) [108]. The mechanism regulating this activation is named the "ribotoxic stress response" [107]. The activation of MAPKs pathway by DON in vivo and in vitro suggests that the ribotoxic stress response mediates DON toxicity [109]. MAPKs are involved in cell growth, differentiation and apoptosis [108]. Additionally, it might include leukocyte apoptosis and lymphotoxicity [110].

Leukocytes are target to DON and trichothecenes mycotoxicosis [110]. As described previously, DON is both immunostimulatory and immunosuppressive and it has been reported that at high doses, DON is immunosuppressive and causes leukocyte apoptosis [111]. The apoptosis was induced by the activation of c-Jun terminal kinase, p38 mitogen-activated protein kinase and caspases. At high doses, trichothecenes produced injuries in spleen, thymus, bone marrow, and intestinal mucosa, leading to immunosuppression, and potentially increased susceptibility to several pathogens [112]. Exposure to high DON concentrations induces macrophages apoptosis which can lead to innate immune function suppression [101]. Moreover, the acute oral exposure to trichothecene mycotoxins produced adverse effects to actively dividing cells in bone marrow, lymph nodes, spleen, thymus, and intestinal mucosa [110].

Trichothecenes have both effects of enhancement or impairment of mitogen-induced lymphocyte proliferation, depending on the dose of exposure, what has been demonstrated in in vitro and ex-vivo studies [111]. In vitro DON exposure induced apoptosis in murine $\mathrm{T}$ cells, B cells, and IgA+ cells isolated from spleen, Peyer's patches, and thymus [113]. This induction of apoptosis was dependent on lymphocyte subset, tissue source, and glucocorticoid induction [110]. In vitro lymphotoxicity of type B and type A trichothecenes depends on the degree of acylation in substituent groups, according to Pestka et al. [111]. Furthermore, Sharma [114] noted that lymphocytes cytotoxicity is a result of a DON immunotoxic effect. DON has the ability to promote in vitro apoptosis in chicken spleen lymphocytes and tissue $[54,115]$. Ingestion of DON from 5.9 to $9.5 \mathrm{mg} / \mathrm{kg}$ feed reduced the B cells and T cells counts in broiler chickens [53]. In the in vivo study conducted by Ghareeb et al. [27] blood lymphocytes count was decreased in broilers receiving DON $(10 \mathrm{mg} / \mathrm{kg}$ feed) for 35 days.

The observed changes on leukocytes and lymphocytes in mycotoxicosis conditions can be attributed to the immune system being sensitive to DON [10]. 


\subsubsection{Production of Proinflammatory Cytokines}

After MAPKs activation, p38 and ERK induced gene transcription and enhanced mRNA stability [107]. The induction of genes expression included also the induction of transcription and post transcriptional factors, such as nuclear factor $\mathrm{k} \beta$ (NF-k $\beta$ ) and leads to promote proinflammatory genes $[107,108]$. Proinflammatory cytokines might serve as relevant biomarkers of effect that are predictive of DON's negative effects in target animals.

The gene expression of interferon gamma (IFN- $\gamma$ ) in the cecal tonsils of chickens fed Fusarium mycotoxins challenged with coccidian was upregulated [105]. Broiler chickens exposed to a mixture of mycotoxins, in which DON concentration was approximately $2 \mathrm{mg} / \mathrm{kg}$, for 42 days had higher expression of interleukin 1- $\beta$ (IL1- $\beta$ ) and IL-6 and lower expression of IFN- $\gamma$ in spleen tissues [104]. In a recent study conducted by Lucke et al. [102], the gene expression of IL- 6 was increased in broilers receiving up $5 \mathrm{mg} / \mathrm{kg}$ for 35 days. Similarly, DON at $5 \mathrm{mg} / \mathrm{kg}$ feed upregulated the relative gene expression of IL-6, IL1- $\beta$ and IFN- $\gamma$ in broiler chickens at 42 days.

The upregulation of cytokine gene expression by DON was explained by the ability of this mycotoxin to inhibit synthesis of labile protein repressors of mRNA expression $[105,116]$. Zhou et al. confirmed that the induction of gene expression of cytokines is a result of DON-induced transient expression of specific mRNAs responsible for impairment of synthesis of high turnover proteins [117]. It has been suggested also that this induction of immune related genes by DON mycotoxin is associated to a higher transcription factor's binding activity in leukocytes at the transcription level and to a higher mRNA stability at the post-transcription level $[101,105]$. In addition to that, the upregulation of cytokines production is linked to the transcription factor NF- $\mathrm{KB}$ activation [108].

However, in response to DON (10 mg/ $\mathrm{kg}$ feed), broiler chickens had lower LITAF in plasma and lower IL-1 $\beta$, IFN- $\gamma$ and TGFBR1 in jejunum, and no effect was observed on plasma IL-8 and LITAF nor on IL-8 and NF-kB1 in the jejunum [106]. Grenier et al. [103] reported a downregulation of IL-6 in cecal tonsils in broiler fed $1.6 \mathrm{mg} \mathrm{DON} / \mathrm{kg}$ feed. No effect on LITAF and IL-1 $\beta$ in spleen and bursa of Fabricius tissues was observed in broilers exposed to $5 \mathrm{mg} / \mathrm{kg}$ DON for 28 days [50]. The differences obtained among studies regarding the DON effect on cytokines production depends on the biological matrix. For example, the determination of cytokines in serum could be a nonsuitable indicator to evaluate the cytokine production due to their short-half-life or due to the low sensitivity of the method used [117]. Another explanation could be the modulating effect of DON on the innate immune response [106]. The ability of DON to upregulate cytokines release is associated to the effect of DON on the innate immune response, leading to the impairment of chicken's resistance to infectious disease [106]. Furthermore, DON-induced proinflammatory cytokines can be useful in the underlying cause of DON-induced feed refusal. Infection induced anorexia could be explained by the upregulation of relative gene expression of IL-1 $\beta$ andIL-6 [118].

\subsection{Biomarkers Related to Welfare Parameters}

To evaluate welfare related parameters induced by DON toxicity in chickens, the indicators linked with oxidative stress and to physiological, hormonal, and behavioral welfare are highlighted in Table 7.

\subsubsection{Response to Oxidative Stress as Welfare Biomarker}

DON induces oxidative stress, which is defined as the imbalance between the reactive oxygen species (ROS) and the antioxidant defenses [125]. DON exposure to chicken's exposure to DON induced the overproduction of free radicals, such as the upregulation of the hypoxia inducible factor 1, subunit alpha (HIF-1 $\alpha$ ) and heme-oxygenase (HMOX) in jejunum and xanthine oxidoreductase in the liver of broiler chickens exposed to $7.54 \mathrm{mg}$ DON $/ \mathrm{kg}$ contaminated feed for 21 days [81]. An increased production of ROS leads to DNA damage, protein oxidation and lipid peroxidation [126]. The exposure of broiler chickens exposed to DON $(10 \mathrm{mg} / \mathrm{kg}$ feed) resulted in DNA damage in spleen leukocytes or in blood lympho- 
cytes [76,121,122]. Regarding the parameters associated with lipid peroxidation, it has been reported that DON increased thiobarbituric acid reactive substances (TBARS) in jejunum and malondialdehyde (MDA) in liver, kidney, serum, and jejunum $[76,83,120,123]$. On the other hand, the oxidative stress is characterized by a reduction in cellular antioxidant levels with a decreased activity of antioxidant enzymes such as superoxidase dismutase (SOD), catalase (CAT) and glutathione-related systems (GSH), including glutathione peroxidase (GPx) [126]. In vivo and in vitro studies reported lower levels of SOD in serum [83], GSH in the liver of broilers [120], and both parameters in chicken embryo fibroblast DF-1 cells after DON exposure [119]. The ingestion of DON reduced the GSH in liver, jejunum and ileum, the 2,2'-azino-bis (3- ethylbenzothiazoline-6-sulphonic acid) (ABTS) in the jejunum, and the ferric reducing ability (FRAP) in liver of broilers chickens [123]. Oxidative stress data may constitute an effective source of information to know the bird's welfare assessment.

Table 7. Effects of deoxynivalenol (DON) on welfare related parameters in chickens.

\begin{tabular}{|c|c|c|c|}
\hline $\mathrm{DON}^{1}(\mathrm{mg} / \mathrm{kg})$ Diet & Exposure Duration (Days) & Reported Effects ${ }^{2}$ & Reference \\
\hline \multicolumn{4}{|c|}{ Response to oxidative stress as welfare biomarker } \\
\hline $100-2000 \mathrm{ng} / \mathrm{mL}$ & $24 \mathrm{~h}$ & $\uparrow$ ROS and MDA, $\downarrow$ GSH and SOD in embryo fibroblast DF- 1 cells & [119] \\
\hline 7.54 & 21 & $\begin{array}{l}\uparrow \mathrm{HIF}-1 \alpha \text { and HMOX in jejunum } \\
\uparrow \text { xanthine oxidoreductase in liver }\end{array}$ & [81] \\
\hline 3.4 or 8.2 & 14 & $\uparrow$ MDA in liver, kidney and serum, $\downarrow$ GPx activity in liver tissue & [120] \\
\hline 10 & 35 & $\begin{array}{c}\uparrow \text { TBARS in jejunum } \\
\text { DNA damage in blood lymphocytes }\end{array}$ & [76] \\
\hline 10 & 42 & $\downarrow$ SOD activity in serum and $\uparrow$ MDA or TBARS in the jejunal mucosa & [83] \\
\hline 10 & 17 & $\begin{array}{c}\uparrow \text { DNA fragmentation in spleen leukocytes } \\
\text { No effect on plasma and liver MDA }\end{array}$ & [121] \\
\hline 10 & 35 & $\begin{array}{l}\uparrow \text { blood lymphocyte DNA damage } \\
\text { No effect on TBARS }\end{array}$ & [122] \\
\hline 19.3 & 14 & $\begin{array}{c}\uparrow \text { TBARS in jejunum } \\
\text { No effects on superoxide anion levels of jejunum and ileum } \\
\downarrow \text { GSH and ABTS in jejunum }\end{array}$ & [123] \\
\hline \multicolumn{4}{|c|}{ Biomarkers related to physiological, hormonal, and behavioral welfare } \\
\hline Up to 14 & 35 & No significant effect on $\mathrm{H} / \mathrm{L}$ ratio & [62] \\
\hline 4.6 & 15 & $\uparrow$ plasma corticosterone & [46] \\
\hline 5.9 or 9.5 & 56 & Alterations on brain neurochemistry $\uparrow 5$-hydroxytryptamineand serotonin & [124] \\
\hline 10 & 35 & $\uparrow \mathrm{H} / \mathrm{L}$ ratio & [27] \\
\hline 10 & 35 & $\begin{array}{c}\uparrow \text { plasma corticosterone, } \mathrm{H} / \mathrm{L} \text { ratio, and duration of tonic } \\
\text { immobility reaction. }\end{array}$ & [57] \\
\hline 5 or 15 & 42 & $\begin{array}{l}\downarrow \text { plasma corticosterone } \\
\text { No effect on H/L ratio } \\
\uparrow \text { duration of tonic immobility reaction }\end{array}$ & [91] \\
\hline Up to 18 & 21 & $\uparrow \mathrm{H} / \mathrm{L}$ ratio & [69] \\
\hline
\end{tabular}

${ }^{1}$ DON, deoxynivalenol; ${ }^{2} \mathrm{MDA}$, malondialdehyde; GPx, glutathione peroxidase; TBARS, thiobarbituric acid reactive substances, HIF-1 $\alpha$, hypoxia inducible factor 1, subunit alpha; HMOX, heme-oxygenase; ROS, reactive oxygen species; GSH, glutathione-related systems; SOD, superoxidase dismutase; ABTS, 2, 2'-azino-bis (3- ethylbenzothiazoline-6-sulphonic acid); H/L, heterophil to lymphocyte ratio; $\uparrow$, increase; $\downarrow$, decrease.

\subsubsection{Biomarkers Related to Physiological, Hormonal, and Behavioral Welfare}

Only a few studies have been carried out on the impact of DON contamination of poultry feed on biomarkers related to physiological, hormonal, and behavioral welfare. Onbasilar and Aksoy [127] reported that the impairment of the number of circulating leukocytes, such as heterophils and lymphocytes, is part of the physiological stress. Therefore, the heterophil to lymphocyte ratio $(\mathrm{H} / \mathrm{L})$ was used as a good indicator to evaluate the stress in poultry [128]. 
The stress index was elevated in broilers fed DON (10 or $18 \mathrm{mg} / \mathrm{kg})$ for 21 or 35 days $[27,57,69]$. However, Dänicke et al. [62] did not report significant differences on $\mathrm{H} / \mathrm{L}$ ratio in broilers fed a contaminated diet with a concentration of $14 \mathrm{mg} / \mathrm{kg}$ of DON per $\mathrm{kg}$. Likewise, the $\mathrm{H} / \mathrm{L}$ ratio was higher in broilers fed 5 or $15 \mathrm{mg}$ of DON $/ \mathrm{kg}$ of feed, but this elevation was not statistically significant [91].

The elevation of circulating levels of corticosterone is included also within the physiological stress biomarkers [127]. Antonissen et al. [46] showed that broilers exposed to a DON $(4.6 \mathrm{mg} / \mathrm{kg})$ contaminated diet for 15 days had higher mean plasma corticosterone levels than chickens fed control diet. Similarly, Ghareeb et al. [57] observed that feeding broilers with $10 \mathrm{mg} / \mathrm{kg}$ of DON for 35 days, increased the plasma corticosterone level. The elevation of corticosterone was related with the upregulation of gene expression of IL-1 $\beta$ and IL-6 proinflammatory cytokines [129]. The increase in corticosterone might be associated with the mycotoxin induced increase in susceptibility to infectious diseases [80].

The fear response is a welfare-related behavior evaluated by tonic immobility reaction and can provide more information on chicken's stress status $[57,130]$. The duration of tonic immobility was longer in broilers exposed to $10 \mathrm{or} 15 \mathrm{mg}$ DON $/ \mathrm{kg}[57,91]$. This effect could be related to the adverse effect of DON on brain regional neurochemistry. Indeed, the inclusion of contaminated grains with Fusarium mycotoxin in the diet of broiler chickens for long-term (1-56 days) increased the concentration of 5-hydroxytryptamine (5 HT) in the pons and in the cortex, which is responsible for the regulation of fear [124]. DON-induced stress altered brain neurochemistry of broilers by increasing serotonin levels (strong satiety neurochemical), suggesting that DON caused partial feed refusal and growth suppression [124]. Consequently, these adverse effects on bird's welfare might be associated with the mycotoxin induced increase in sensitivity to infectious diseases.

In summary, the frequencies of effects of biomarkers mentioned in this review are recapitulated in Table 8.

It should be noted that the most frequent effect on these biomarkers appeared at 42 days (Table 8), indicating that sampling time and measurements of biomarkers at 42 days could be suitable to evaluate toxic DON effect on broilers, due to the fact that older birds consume more total mycotoxins, which is estimated by feed intake $(\mathrm{kg}) \mathrm{x}$ dietary mycotoxin levels $(\mathrm{mg} / \mathrm{kg}$ ) [51]. Moreover, the differences in absorption, distribution, metabolism and excretion processes could be age related and then could influence animal's response to mycotoxins [126]. 
Table 8. Frequencies of effects of the nonspecific biomarkers of toxicity of deoxynivalenol (DON) in chickens at starter and grower cycles of growth.

\begin{tabular}{|c|c|c|c|c|c|c|}
\hline \multirow{2}{*}{ Biomarkers Frequently Determined ${ }^{1}$} & \multicolumn{2}{|c|}{ No Effect } & \multicolumn{2}{|c|}{$\uparrow$, Increase } & \multicolumn{2}{|c|}{$\downarrow$, Decrease } \\
\hline & Starter (at 21 Days) & Grower (from 21 Days) & Starter (at 21 Days) & Grower (from 21 Days) & Starter (at 21 Days) & Grower (from 21 Days \\
\hline Productive parameters & {$[46,48,67,71]$} & {$[45,50,57-60]$} & [68] & {$[31,47,52,54,68,70]$} & {$[33,49,61,63-66,69]$} & {$[19,27,51,53,55,56,62]$} \\
\hline \multicolumn{7}{|l|}{ RW of organs } \\
\hline Liver & [63-67] & {$[19,33,45,53,62,70,76]$} & & [61] & & {$[55,68]$} \\
\hline Kidneys & [63-67] & {$[19,45,53,62,68,70]$} & & & & [76] \\
\hline Gizzard & {$[49,67]$} & {$[33,45,62,77]$} & {$[63-66]$} & {$[19,68,70,76]$} & & \\
\hline Bursa of Fabricius & {$[65,67]$} & {$[19,27,33,53,62,68,70,76]$} & {$[63,66]$} & & & \\
\hline Spleen & {$[49,64-66]$} & {$[19,27,33,53,68,70,76]$} & & {$[54,61]$} & & [62] \\
\hline Thymus & & {$[27,33,61,76]$} & & [19] & & \\
\hline Heart & {$[49,67]$} & {$[19,33,45,61,68,70,76]$} & [63] & [62] & & \\
\hline \multicolumn{7}{|l|}{ Intestinal morphology } \\
\hline Villus height & & {$[19,54]$} & [69] & & {$[49,51,81,82]$} & {$[33,50,60,77,80,83]$} \\
\hline Crypt depth & [69] & {$[19,83]$} & [82] & & {$[51,81]$} & \\
\hline Total protein & & [62] & & & & {$[27,88-90]$} \\
\hline Albumin & & & & & & {$[52,88]$} \\
\hline ALT & [67] & & & {$[88-90]$} & & {$[58]$} \\
\hline ALP & & & & [88] & & \\
\hline AST & [67] & & [63] & {$[88]$} & & \\
\hline Triglycerides & & & & {$[58]$} & [64] & {$[27,68,89,90]$} \\
\hline Glucose & [67] & [62] & & & [65] & {$[68]$} \\
\hline \multicolumn{7}{|l|}{ Blood hematology } \\
\hline Hematocrit & [92] & [62] & & & {$[64]$} & {$[68,92]$} \\
\hline Hemoglobin & {$[67,92]$} & [62] & & & {$[64]$} & {$[52,68,70,91,92]$} \\
\hline Erythrocytes & [92] & & & & {$[64]$} & {$[52,91,92]$} \\
\hline Lymphocytes & & & & & & {$[27,53,54]$} \\
\hline
\end{tabular}


Table 8. Cont.

\begin{tabular}{|c|c|c|c|c|c|c|}
\hline \multirow{2}{*}{ Biomarkers Frequently Determined ${ }^{1}$} & \multicolumn{2}{|c|}{ No Effect } & \multicolumn{2}{|c|}{$\uparrow$, Increase } & \multicolumn{2}{|c|}{$\downarrow$, Decrease } \\
\hline & Starter (at 21 Days) & Grower (from 21 Days) & Starter (at 21 Days) & Grower (from 21 Days) & Starter (at 21 Days) & Grower (from 21 Days) \\
\hline \multicolumn{7}{|l|}{ Response to common vaccines } \\
\hline NDV & & {$[91,92]$} & [61] & [61] & & {$[62,92,104]$} \\
\hline IBV & & {$[52,91]$} & & & & {$[27,58,61]$} \\
\hline \multicolumn{7}{|l|}{ Cytokines } \\
\hline IL-6 & & & & {$[91,102,104]$} & & [103] \\
\hline IL-8 & & [106] & & [91] & & [102] \\
\hline IL-1 $\beta$ & & {$[50,103]$} & & {$[91,104]$} & & [106] \\
\hline IFN- $\gamma$ & & [103] & & {$[91,105]$} & & {$[104,106]$} \\
\hline \multicolumn{7}{|l|}{ Oxidative stress parameters } \\
\hline MDA & [121] & & [120] & [83] & & \\
\hline TBARS & & [122] & [123] & {$[76,83]$} & & \\
\hline \multicolumn{7}{|l|}{ Physiological stress parameters } \\
\hline Stress index (H/L ratio) & & {$[62,91]$} & & {$[27,57,69]$} & & \\
\hline
\end{tabular}

\section{Stress index (H/L ratio)}

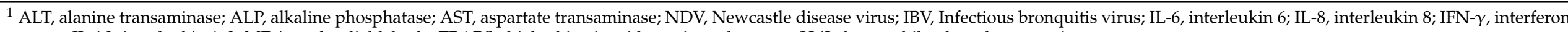
gamma; IL-1 $\beta$, interleukin 1- $\beta$; MDA, malondialdehyde; TBARS, thiobarbituric acid reactive substances; H/L, heterophil to lymphocyte ratio. 


\section{Conclusions}

To conclude, DON-3S is the specific and the most suitable biomarker of exposure of DON in chicken. The metabolic pathway that causes its formation could be considered as a detoxification pathway in those animals, which probably explains the low susceptibility to DON mycotoxicosis compared to other species. However further studies are needed to elucidate exactly the metabolism leading from DON to DON-3S in poultry.

Among the biomarkers of effect highlighted in this review, the most relevant ones are productive parameters, relative weight of gizzard, villus height, blood protein, triglycerides, alanine transaminase, hemoglobin, erythrocytes, lymphocytes, response to NDV and IBV, and stress index (H/L ratio). Intestinal cytokines (IL-6, IL-8, IL-1 $\beta$, and IFN- $\gamma$ ), and TBARS as an oxidative stress parameter could be also relevant biomarkers of toxicity of DON in chickens.

DON could alter the production and bird's health status through multiple pathways. The biochemical and hematological alteration suggests the malfunctioning of immune system. Furthermore, the intestinal alteration leads to the alteration on the absorption and digestion process. The induction of proinflammatory release, corticosterone secretion and oxidative stress, are involved in feed refusal and increased the susceptibility to infectious disease. Studies cited in the current review were under experimental conditions, however, it would be necessary to increase the proportion of research undertaken in field conditions.

Author Contributions: I.R. wrote the original draft preparation and edited the version revised by V.M., A.M.P.-V., A.J.R., J.B., E.E.-G. and J.S. All authors have read and agreed to the published version of the manuscript.

Funding: This research was funded by PHILEO BY LESAFFRE.

Institutional Review Board Statement: Not applicable.

Informed Consent Statement: Not applicable.

Data Availability Statement: Not applicable.

Acknowledgments: Insaf Riahi gratefully acknowledges Phileo by Lesaffre for their pre-doctoral grant. Insaf Riahi thanks Enric Esteve-Garcia for the linguistic revision.

Conflicts of Interest: The authors declare no conflict of interest.

\section{References}

1. OECD/FAO. OECD-FAO Agricultural Outlook; OECD Agriculture Statistics (Database): Paris, France, 2020; Available online: https://www.oecd-ilibrary.org/agriculture-and-food/data/oecd-agriculture-statistics_agr-data-en (accessed on 5 March 2021).

2. Fokunang, C.N.; Tembe-Fokunang, E.A.; Tomkins, P.; Barkwan, S. Global impact of mycotoxins on human and animal health management. Outlook Agric. 2006, 35, 247-253. [CrossRef]

3. Sharma, R.; Asrani, R.K.; Station, R. Mycotoxicosis and its control in poultry: A review. J. Poult. Sci. Technol. 2014, 2, 01-10.

4. Haque, M.A.; Wang, Y.; Shen, Z.; Li, X.; Saleemi, M.K.; He, C. Mycotoxin contamination and control strategy in human, domestic animal and poultry: A review. Microb. Pathog. 2020, 142, 104095. [CrossRef]

5. Murugesan, G.R.; Ledoux, D.R.; Naehrer, K.; Berthiller, F.; Applegate, T.J.; Grenier, B.; Phillips, T.D.; Schatzmayr, G. Prevalence and effects of mycotoxins on poultry health and performance, and recent development in mycotoxin counteracting strategies. Poult. Sci. 2015, 94, 1298-1315. [CrossRef]

6. Creppy, E.E. Update of survey, regulation and toxic effects of mycotoxins in Europe. Toxicol. Lett. 2002, 127, 19-28. [CrossRef]

7. Gruber-Dorninger, C.; Jenkins, T.; Shatzmayr, G. Global mycotoxin occurrence in feed: A ten year survey. Toxins 2019, 11, 375. [CrossRef]

8. Bertero, A.; Moretti, A.; Spicer, L.J.; Caloni, F. Fusarium molds and mycotoxins: Potential species-specific effects. Toxins 2018, 10, 244. [CrossRef] [PubMed]

9. Ma, Y.Y.; Guo, H.W. Mini-review of studies on the carcinogenicity of deoxynivalenol. Environ Toxico Pharmacol. 2008, 25, 1-9. [CrossRef] [PubMed]

10. Escrivá, L.; Font, G.; Manyes, L. In vivo toxicity studies of Fusarium mycotoxins in the last decade: A review. Food Chem. Toxicol. 2015, 78, 185-206. [CrossRef]

11. Nagy, C.M.; Fejer, S.N.; Berek, L.; Molnar, J.; Viskolcz, B. Hydrogen bondings in deoxynivalenol (DON) conformations-A density functional study. J. Mol. Struct. 2005, 726, 55-59. [CrossRef] 
12. Wolf, C.E.; Bullerman, L.B. Heat and $\mathrm{pH}$ alter the concentration of deoxynivalenol in an aqueous enviroment. J. Food Prot. 1998, 61, 365-367. [CrossRef] [PubMed]

13. Ostry, V.; Malir, F.; Toman, J.; Grosse, Y. Mycotoxins as human carcinogens-the IARC Monographs classification. Mycotoxin Res. 2017, 33, 65-73. [CrossRef] [PubMed]

14. Feinberg, B.; Mclaughlin, C.S. Biochemical Mechanism of Action of Trichothecene Mycotoxins. In Trichothecene Mycotoxicosis: Pathophysiologic Effects; Beasley, V.R., Ed.; CRC Press: Boca Raton, FL, USA, 1989; Volume I, pp. 27-35.

15. Shifrin, V.I.; Anderson, P. Trichothecene mycotoxins trigger a ribotoxic stress response that activates c-Jun N-terminal kinase and p38 mitogen-activated protein kinase and induces apoptosis. J. Biol. Chem. 1999, 274, 13985-13992. [CrossRef]

16. Mishra, S.; Dwivedi, P.D.; Pandey, H.P.; Das, M. Role of oxidative stress in Deoxynivalenol induced toxicity. Food Chem. Toxicol. 2014, 72, 20-29. [CrossRef] [PubMed]

17. Huff, W.E.; Doerr, J.A.; Hamilton, P.B.; Vesonder, R.F. Acute toxicity of vomitoxin (Deoxynivalenol) in broiler chickens. Poult. Sci. 1981, 60, 1412-1414. [CrossRef]

18. Surai, P.F.; Dvorska, J.E.; Sparks, N.H.C.; Jacques, K.A. Impact of mycotoxins on the body' s antioxidant defence. In Nutritional Biotechnology in the Feed and Food Industries; Nottingham University: Nottingham, UK, 1999; pp. 131-141.

19. Riahi, I.; Marquis, V.; Ramos, A.J.; Brufau, J.; Esteve-Garcia, E.; Pérez-Vendrell, A.M. Effects of deoxynivalenol contaminated-diets on productive, morphological, and physiological indicators in broiler chickens. Animals 2020, 10, 1795. [CrossRef] [PubMed]

20. Aguzey, H.A.; Gao, Z.; Haohao, W.; Guilan, C.; Zhengmin, W.; Junhong, C. The Effects of Deoxynivalenol (DON) on the Gut Microbiota, Morphology and Immune System of Chicken-A Review. Ann. Anim. Sci. 2019, 19, 305-318. [CrossRef]

21. Pinton, P.; Oswald, I.P. Trichothecenes on the Intestine: A Review. Toxins 2014, 6, 1615-1643. [CrossRef] [PubMed]

22. Broekaert, N.; Devreese, M.; De Mil, T.; Fraeyman, S.; Antonissen, G.; De Baere, S.; De Backer, P.; Vermeulen, A.; Croubels, S. Oral Bioavailability, Hydrolysis, and Comparative Toxicokinetics of 3-Acetyldeoxynivalenol and 15-Acetyldeoxynivalenol in Broiler Chickens and Pigs. J. Agric. Food Chem. 2015, 63, 8734-8742. [CrossRef] [PubMed]

23. European Commission Commission Recommendation of 17 August 2006 on the presence of deoxynivalenol, zearalenone, ochratoxin A, T-2 and HT-2 and fumonisins inproducts intended for animal feeding. Off. J. Eur. Union 2006, L299, 7-9.

24. Kolosova, A.; Stroka, J. Substances for reduction of the contamination of feed by mycotoxins: A review. World Mycotoxin J. 2011, 4, 225-256. [CrossRef]

25. Research and Markets. Global Feed Mycotoxin Detoxifiers Market-Growth, Trends and Forecasts (2020-2025). Research and Markets: Dublin, Ireland. 2020. Available online: https:/ / www.researchandmarkets.com/reports/4772013/global-feedmycotoxin-detoxifiers-market (accessed on 5 March 2021).

26. Atkinson, A.J.; Colburn, W.A.; DeGruttola, V.G.; DeMets, D.L.; Downing, G.J.; Hoth, D.F.; Oates, J.A.; Peck, C.C.; Schooley, R.T.; Spilker, B.A.; et al. Biomarkers and surrogate endpoints: Preferred definitions and conceptual framework. Clin. Pharmacol. Ther. 2001, 69, 89-95. [CrossRef]

27. Ghareeb, K.; Awad, W.A.; Böhm, J. Ameliorative effect of a microbial feed additive on infectious bronchitis virus antibody titer and stress index in broiler chicks fed deoxynivalenol. Poult. Sci. 2012, 91, 800-807. [CrossRef] [PubMed]

28. EFSA Panel on Additives and Products or Substances used in Animal Feed (FEEDAP). EFSA Statement on the establishment of guidelines for the assessment of additives from the functional group 'substances for reduction of the contamination of feed by mycotoxins'. EFSA J. 2010, 8, 1963.

29. Vidal, A.; Mengelers, M.; Yang, S.; De Saeger, S.; De Boevre, M. Mycotoxin Biomarkers of Exposure: A Comprehensive Review. Compr. Rev. Food Sci. Food Saf. 2018, 17, 1127-1155. [CrossRef]

30. Devreese, M.; Antonissen, G.; Broekaert, N.; De Mil, T.; De Baere, S.; Vanhaecke, L.; De Backer, P.; Croubels, S. Toxicokinetic study and oral bioavailability of deoxynivalenol in Turkey poults, and comparative biotransformation between broilers and Turkeys. World Mycotoxin J. 2015, 8, 533-539. [CrossRef]

31. Dänicke, S.; Valenta, H.; Ueberschär, K.H.; Matthes, S. On the interactions between Fusarium toxin-contaminated wheat and non-starch-polysaccharide hydrolyzing enzymes in diet of broilers on performance, intestinal viscosity and carry-over of deoxynivalenol. Poult. Sci. 2007, 85, 291-298. [CrossRef] [PubMed]

32. Yunus, A.W.; Valenta, H.; Abdel-Raheem, S.M.; Döll, S.; Dänicke, S.; Böhm, J. Blood plasma levels of deoxynivalenol and its de-epoxy metabolite in broilers after a single oral dose of the toxin. Mycotoxin Res. 2010, 26, 217-220. [CrossRef]

33. Awad, W.A.; Hess, M.; Twaruzek, M.; Grajewski, J.; Kosicki, R.; Böhm, J.; Zentek, J. The impact of the Fusarium mycotoxin deoxynivalenol on the health and performance of broiler chickens. Int. J. Mol. Sci. 2011, 12, 7996-8012. [CrossRef]

34. Osselaere, A.; Devreese, M.; Watteyn, A.; Vandenbroucke, V.; Goossens, J.; Hautekiet, V.; Eeckhout, M.; De Saeger, S.; De Baere, S.; De Backer, P.; et al. Efficacy and safety testing of mycotoxin-detoxifying agents in broilers following the European Food Safety Authority guidelines. Poult. Sci. 2012, 91, 2046-2054. [CrossRef] [PubMed]

35. Wan, D.; Huang, L.; Pan, Y.; Wu, Q.; Chen, D.; Tao, Y.; Wang, X.; Liu, Z.; Li, J.; Wang, L.; et al. Metabolism, distribution, and excretion of deoxynivalenol with combined techniques of radiotracing, high-performance liquid chromatography ion trap time-of-flight mass spectrometry, and online radiometric detection. J. Agric. Food Chem. 2014, 62, 288-296. [CrossRef]

36. Schwartz-Zimmermann, H.E.; Fruhmann, P.; Dänicke, S.; Wiesenberger, G.; Caha, S.; Weber, J.; Berthiller, F. Metabolism of deoxynivalenol and deepoxy-deoxynivalenol in broiler chickens, pullets, roosters and turkeys. Toxins 2015, 7, 4706-4729. [CrossRef] 
37. Lauwers, M.; Croubels, S.; Letor, B.; Gougoulias, C.; Devreese, M. Biomarkers for exposure as a tool for efficacy testing of a mycotoxin detoxifier in broiler chickens and pigs. Toxins 2019,11, 187. [CrossRef]

38. Osselaere, A.; Devreese, M.; Goossens, J.; Vandenbroucke, V.; De Baere, S.; De Backer, P.; Croubels, S. Toxicokinetic study and absolute oral bioavailability of deoxynivalenol, T-2 toxin and zearalenone in broiler chickens. Food Chem. Toxicol. 2013, 51, 350-355. [CrossRef] [PubMed]

39. Broekaert, N.; Devreese, M.; De Mil, T.; Fraeyman, S.; De Baere, S.; De Saeger, S.; De Backer, P.; Croubels, S. Development and validation of an LC-MS/MS method for the toxicokinetic study of deoxynivalenol and its acetylated derivatives in chicken and pig plasma. J. Chromatogr. B Anal. Technol. Biomed. Life Sci. 2014, 971, 43-51. [CrossRef]

40. Broekaert, N.; Devreese, M.; van Bergen, T.; Schauvliege, S.; De Boevre, M.; De Saeger, S.; Vanhaecke, L.; Berthiller, F.; Michlmayr, H.; Malachová, A.; et al. In vivo contribution of deoxynivalenol-3- $\beta$-d-glucoside to deoxynivalenol exposure in broiler chickens and pigs: oral bioavailability, hydrolysis and toxicokinetics. Arch. Toxicol. 2017, 91, 699-712. [CrossRef] [PubMed]

41. Boudergue, C.; Burel, C.; Dragacci, S.; Favrot, M.; Fremy, J.; Massimi, C.; Prigent, P.; Debongnie, P.; Pussemier, L.; Boudra, H.; et al. Review of mycotoxin-detoxifying agents used as feed additives: Mode of action, efficacy and feed/food safety. EFSA Support. Publ. 2017, 6. [CrossRef]

42. Antonissen, G.; Haesendonck, R.; Devreese, M.; Broekaert, N.; Verbrugghe, E.; De Saeger, S.; Audenaert, K.; Haesebrouck, F.; Pasmans, F.; Ducatelle, R.; et al. The impact of deoxynivalenol on pigeon health: Occurrence in feed, toxicokinetics and interaction with salmonellosis. PLoS ONE 2016, 11, 1-14. [CrossRef] [PubMed]

43. Jurisic, N.; Schwartz-Zimmermann, H.E.; Kunz-Vekiru, E.; Reisinger, N.; Klein, S.; Caldwell, D.; Fruhmann, P.; Schatzmayr, D.; Berthiller, F. Deoxynivalenol-3-sulphate is the major metabolite of dietary deoxynivalenol in eggs of laying hens. World Mycotoxin J. 2019, 12, 245-255. [CrossRef]

44. Yi, L.; Dratter, J.; Wang, C.; Tunge, J.A.; Desaire, H. Identification of sulfation sites of metabolites and prediction of the compounds biological effects. Anal. Bioanal. Chem. 2006, 386, 666-674. [CrossRef]

45. Hulan, H.W.; Proudfoot, F.G. Effects of feeding vomitoxin contaminated wheat on the performance of broiler chickens. Poult. Sci. 1982, 61, 1653-1659. [CrossRef]

46. Antonissen, G.; De Baere, S.; Devreese, M.; Van Immerseel, F.; Martel, A.; Croubels, S. Feed contamination with Fusarium mycotoxins induces a corticosterone stress response in broiler chickens. Poult. Sci. 2017, 96, 14-17. [CrossRef] [PubMed]

47. Hamilton, R.M.G.; Trenholm, H.L.; Thompson, B.K.; Greenhalgh, R. The tolerance of White Leghorn and broiler chicks, and turkey poults to diets that contained deoxynivalenol (vomitoxin)-contaminated wheat. Poult. Sci. 1985, 64, 273-286. [CrossRef] [PubMed]

48. Liu, J.D.; Doupovec, B.; Schatzmayr, D.; Murugesan, G.R.; Bortoluzzi, C.; Villegas, A.M.; Applegate, T.J. The impact of deoxynivalenol, fumonisins, and their combination on performance, nutrient, and energy digestibility in broiler chickens. Poult. Sci. 2020, 99, 272-279. [CrossRef]

49. Awad, W.A.; Böhm, J.; Razzazi-Fazeli, E.; Zentek, J. Effects of feeding deoxynivalenol contaminated wheat on growth performance, organ weights and histological parameters of the intestine of broiler chickens. J. Anim. Physiol. Anim. Nutr. 2006, 90, 32-37. [CrossRef]

50. Yu, Y.H.; Hsiao, F.S.H.; Proskura, W.S.; Dybus, A.; Siao, Y.H.; Cheng, Y.H. An impact of Deoxynivalenol produced by Fusarium graminearum on broiler chickens. J. Anim. Physiol. Anim. Nutr. 2018, 102, 1012-1019. [CrossRef] [PubMed]

51. Wang, A.; Hogan, N.S. Performance effects of feed-borne Fusarium mycotoxins on broiler chickens: Influences of timing and duration of exposure. Anim. Nutr. 2019, 5, 32-40. [CrossRef]

52. Swamy, H.V.L.N.; Smith, T.K.; Cotter, P.F.; Boermans, H.J.; Sefton, A.E. Effects of feeding blends of grains naturally contaminated with Fusarium mycotoxins on production and metabolism in broilers. Poult. Sci. 2002, 81, 966-975. [CrossRef] [PubMed]

53. Swamy, H.V.L.N.; Smith, T.K.; Karrow, N.A.; Boermans, H.J. Effects of feeding blends of grains naturally contaminated with Fusarium mycotoxins on growth and immunological parameters of broiler chickens. Poult. Sci. 2004, 83, 533-543. [CrossRef] [PubMed]

54. Chen, S.S.; Li, Y.H.; Lin, M.F. Chronic exposure to the Fusarium mycotoxin deoxynivalenol: Impact on performance, immune organ, and intestinal integrity of slow-growing chickens. Toxins 2017, 9, 334. [CrossRef]

55. Lucke, A.; Doupovec, B.; Paulsen, P.; Zebeli, Q.; Böhm, J. Effects of low to moderate levels of deoxynivalenol on feed and water intake, weight gain, and slaughtering traits of broiler chickens. Mycotoxin Res. 2017, 33, 261-271. [CrossRef]

56. Awad, W.A.; Ruhnau, D.; Hess, C.; Doupovec, B.; Schatzmayr, D.; Hess, M. Feeding of deoxynivalenol increases the intestinal paracellular permeability of broiler chickens. Arch. Toxicol. 2019, 93, 2057-2064. [CrossRef]

57. Ghareeb, K.; Awad, W.A.; Sid-Ahmed, O.E.; Böhm, J. Insights on the host stress, fear and growth responses to the deoxynivalenol feed contaminant in broiler chickens. PLoS ONE 2014, 9. [CrossRef]

58. Ghareeb, K.; Awad, W.A.; Zebeli, Q.; Böhm, J. Deoxynivalenol in chicken feed alters the vaccinal immune response and clinical biochemical serum parameters but not the intestinal and carcass characteristics. J. Anim. Physiol. Anim. Nutr. 2016, 100, 53-60. [CrossRef]

59. Awad, W.A.; Böhm, J.; Razzazi-Fazeli, E.; Hulan, H.W.; Zentek, J. Effects of deoxynivalenol on general performance and electrophysiological properties of intestinal mucosa of broiler chickens. Poult. Sci. 2004, 83, 1964-1972. [CrossRef] 
60. Awad, W.A.; Böhm, J.; Razzazi-Fazeli, E.; Ghareeb, K.; Zentek, J. Effect of addition of a probiotic microorganism to broiler diets contaminated with deoxynivalenol on performance and histological alterations of intestinal villi of broiler chickens. Poult. Sci. 2006, 85, 974-979. [CrossRef]

61. Yunus, A.W.; Ghareeb, K.; Twaruzek, M.; Grajewski, J.; Böhm, J. Deoxynivalenol as a contaminant of broiler feed: Effects on bird performance and response to common vaccines. Poult. Sci. 2012, 91, 844-851. [CrossRef]

62. Dänicke, S.; Matthes, S.; Halle, I.; Ueberschär, K.H.; Döll, S.; Valenta, H. Effects of graded levels of Fusarium toxin-contaminated wheat and of a detoxifying agent in broiler diets on performance, nutrient digestibility and blood chemical parameters. Br. Poult. Sci. 2003, 44, 113-126. [CrossRef] [PubMed]

63. Kubena, L.F.; Edrington, T.S.; Harvey, R.B.; Buckley, S.A.; Phillips, T.D.; Rottinghaus, G.E.; Casper, H.H. Individual and Combined Effects of Fumonisin B1 Present in Fusarium moniliforme Culture Material and T-2 Toxin or Deoxynivalenol in Broiler Chicks. Poult. Sci. 1997, 76, 1239-1247. [CrossRef]

64. Huff, W.E.; Kubena, L.F.; Harvey, R.B.; Halger, W.M.; Swanson, S.P.; Philips, T.C.; Greger, C. Individual and combined effects of aflatoxin and deoxynivalenol (DON), vomitoxin in broiler chickens. Poult. Sci. 1986, 65, 1291-1298. [CrossRef]

65. Kubena, L.F.; Huff, W.E.; Harvey, R.B.; Corrier, D.E.; Phillips, T.D.; Creger, C.R. Influence of ochratoxin A and deoxynivalenol on growing broiler chicks. Poult. Sci. 1988, 67, 253-260. [CrossRef]

66. Kubena, L.F.; Huff, W.E.; Harvey, R.B.; Phillips, T.D.; Rottinghaus, G.E. Individual and combined toxicity of deoxynivalenol and T-2 toxin in broiler chicks. Poult. Sci. 1989, 68, 622-626. [CrossRef]

67. Harvey, R.B.; Kubena, L.F.; Rottinghaus, G.E.; Turk, J.R.; Casper, H.H.; Buckley, S.A. Moniliformin from Fusarium fujikuroi Culture Material and Deoxynivalenol from Naturally Contaminated Wheat Incorporated into Diets of Broiler Chicks. Avian Dis. 1997, 41, 957. [CrossRef]

68. Kubena, L.F.; Swanson, S.P.; Harvey, R.B.; Rowe, L.D.; Phillips, T.D. Effects of Feeding Deoxynivalenol (Vomitoxin)-Contaminated Wheat to growing chicks. Poult.Sci. 1985, 64, 1649-1655. [CrossRef]

69. Xu, L.; Eicher, S.D.; Applegate, T.J. Effects of increasing dietary concentrations of corn naturally contaminated with deoxynivalenol on broiler and Turkey poult performance and response to lipopolysaccharide. Poult. Sci. 2011, 90, 2766-2774. [CrossRef] [PubMed]

70. Kubena, L.F.; Harvey, R.B. Response of growing Leghorn chicks to deoxynivalenol-contaminated wheat. Poult. Sci. 1988, 67, 1778-1780. [CrossRef]

71. Moran, E.T.; Hunter, B.; Ferket, P.; Young, L.G.; McGirr, L.G. High tolerance of broilers to vomitoxin from corn infected with Fusarium graminearum. Poult. Sci. 1982, 61, 1828-1831. [CrossRef] [PubMed]

72. Andretta, I.; Kipper, M.; Lehnen, C.R.; Hauschild, L.; Vale, M.M.; Lovatto, P.A. Meta-analytical study of productive and nutritional interactions of mycotoxins in broilers. Poult. Sci. 2011, 90, 1934-1940. [CrossRef]

73. Cheema, M.A.; Qureshi, M.A.; Havenstein, G.B.; Ferket, P.R.; Nestor, K.E. A comparison of the immune response of 2003 commercial Turkeys and a 1966 randombred strain when fed representative 2003 and 1966 Turkey diets. Poult. Sci. 2007, 86, 241-248. [CrossRef]

74. Grenier, B.; Oswald, I.P. Mycotoxin co-contamination of food and feed: Meta-analysis of publications describing toxicological interactions. World Mycotoxin J. 2011, 4, 285-313. [CrossRef]

75. Knutsen, H.K.; Alexander, J.; Barregård, L.; Bignami, M.; Brüschweiler, B.; Ceccatelli, S.; Cottrill, B.; Dinovi, M.; Grasl-Kraupp, B.; Hogstrand, C.; et al. Risks to human and animal health related to the presence of deoxynivalenol and its acetylated and modified forms in food and feed. EFSA J. 2017, 15. [CrossRef]

76. Awad, W.A.; Ghareeb, K.; Dadak, A.; Hess, M.; Böhm, J. Single and combined effects of deoxynivalenol mycotoxin and a microbial feed additive on lymphocyte DNA damage and oxidative stress in broiler chickens. PLoS ONE 2014, 9, 1-6. [CrossRef] [PubMed]

77. Yunus, A.W.; Blajet-Kosicka, A.; Kosicki, R.; Khan, M.Z.; Rehman, H.; Böhm, J. Deoxynivalenol as a contaminant of broiler feed: Intestinal development, absorptive functionality, and metabolism of the mycotoxin. Poult. Sci. 2012, 91, 852-861. [CrossRef]

78. Awad, W.A.; Ghareeb, K.; Böhm, J.; Razzazi, E.; Hellweg, P.; Zentek, J. The impact of the Fusarium toxin deoxynivalenol (DON) on poultry. Int. J. Poult. Sci. 2008, 7, 827-842. [CrossRef]

79. Ghareeb, K.; Awad, W.A.; Böhm, J.; Zebeli, Q. Impacts of the feed contaminant deoxynivalenol on the intestine of monogastric animals: Poultry and swine. J. Appl. Toxicol. 2015, 35, 327-337. [CrossRef] [PubMed]

80. Antonissen, G.; Van Immerseel, F.; Pasmans, F.; Ducatelle, R.; Haesebrouck, F.; Timbermont, L.; Vertinden, M.; Janssens, G.P.J.; Eeckhaut, V.; Eeckhout, M.; et al. The mycotoxin deoxynivalenol predisposes for the development of Clostridium perfringensinduced necrotic enteritis in broiler chickens. PLoS ONE 2014, 9, 1-8. [CrossRef]

81. Osselaere, A.; Santos, R.; Hautekiet, V.; De Backer, P.; Chiers, K.; Ducatelle, R.; Croubels, S. Deoxynivalenol Impairs Hepatic and Intestinal Gene Expression of Selected Oxidative Stress, Tight Junction and Inflammation Proteins in Broiler Chickens, but Addition of an Adsorbing Agent Shifts the Effects to the Distal Parts of the Small Intestine. PLoS ONE 2013, 8, 1-7. [CrossRef]

82. Wu, S.; Liu, Y.; Duan, Y.; Wang, F.; Guo, F.; Yan, F.; Yang, X.; Yang, X. Intestinal toxicity of deoxynivalenol is limited by supplementation with Lactobacillus plantarum JM113 and consequentially altered gut microbiota in broiler chickens. J. Anim. Sci. Biotechnol. 2018, 9, 1-13. [CrossRef] [PubMed]

83. Yang, X.; Li, L.; Duan, Y.; Yang, X. Antioxidant activity of lactobacillus plantarum JM113 in vitro and its protective effect on broiler chickens challenged with deoxynivalenol. J. Anim. Sci. 2017, 95, 837-846. [CrossRef]

84. Alizadeh, A.; Braber, S.; Akbari, P.; Garssen, J.; Fink-Gremmels, J. Deoxynivalenol impairs weight gain and affects markers of gut health after low-dose, short-term exposure of growing pigs. Toxins 2015, 7, 2071-2095. [CrossRef] 
85. Robert, H.; Payros, D.; Pinton, P.; Théodorou, V.; Mercier-Bonin, M.; Oswald, I.P. Impact of mycotoxins on the intestine: Are mucus and microbiota new targets? J. Toxicol. Environ. Heal. Part B Crit. Rev. 2017, 20, 249-275. [CrossRef] [PubMed]

86. Grenier, B.; Bracarense, A.P.F.L.; Schwartz, H.E.; Lucioli, J.; Cossalter, A.M.; Moll, W.D.; Schatzmayr, G.; Oswald, I.P. Biotransformation approaches to alleviate the effects induced by Fusarium Mycotoxins in swine. J. Agric. Food Chem. 2013, 61, 6711-6719. [CrossRef] [PubMed]

87. Metayer, J.P.; Travel, A.; Mika, A.; Bailly, J.D.; Cleva, D.; Boissieu, C.; Le Guennec, J.; Froment, P.; Albaric, O.; Labrut, S.; et al. Lack of toxic interaction between fusariotoxins in broiler chickens fed throughout their life at the highest level tolerated in the european union. Toxins 2019, 11, 455. [CrossRef]

88. Katarína, K.; Zita, F.; L’Uba, G.; Faix, Š.; Lucia, M.; Leng, L. Effects of feeding wheat naturally contaminated with Fusarium mycotoxins on blood biochemistry and the effectiveness of dietary lignin treatment to alleviate mycotoxin adverse effects in broiler chickens. Acta Vet. Brno. 2011, 61, 227-237. [CrossRef]

89. Zita, F.; Faix, Š.; Leng, L.; Váczi, P.; Renáta, S.; Zuzana, M. Effects of feeding diet contaminated with deoxynivalenol on plasma chemistry in growing broiler chickens and the efficacy of glucomannan mycotoxin adsorbent. Acta Vet. Brno. 2006, 56, 479-487. [CrossRef]

90. Faixová, Z.; Faix, Š.; Bořutová, R.; Leng, L. Efficacy of dietary selenium to counteract toxicity of deoxynivalenol in growing broiler chickens. Acta Vet. Brno 2007, 76, 349-356. [CrossRef]

91. Riahi, I.; Marquis, V.; Pérez-Vendrell, A.M.; Brufau, J.; Esteve-Garcia, E.; Ramos, A.J. Effects of Deoxynivalenol-Contaminated Diets on Metabolic and Immunological Parameters in Broiler Chickens. Animals 2021, 11, 147. [CrossRef]

92. Harvey, R.B.; Kubena, L.F.; Huff, W.E.; Elissalde, M.H.; Phillips, T.D. Hematologic and immunologic toxicity of deoxynivalenol (DON)-contaminated diets to growing chickens. Bull. Environ. Contam. Toxicol. 1991, 46, 410-416. [CrossRef]

93. Husic, H.D.; Suelter, C.H. The levels of creatine kinase and adenylate kinase in the plasma of dystrophic chickens reflect the rates of loss of these enzymes from the circulation. Biochem. Med. 1983, 29, 318-336. [CrossRef]

94. Andretta, I.; Kipper, M.; Lehnen, C.R.; Lovatto, P.A. Meta-analysis of the relationship of mycotoxins with biochemical and hematological parameters in broilers. Poult. Sci. 2012, 91, 376-382. [CrossRef]

95. Kubena, L.F.; Harvey, R.B.; Corrier, D.E.; Huff, W.E. Effects of feeding deoxynivalenol (DON, vomitoxin)-contaminated wheat to female White Leghorn chickens from day old through egg production. Poult. Sci. 1987, 66, 1612-1618. [CrossRef] [PubMed]

96. Chowdhury, S.R.; Smith, T.K.; Boermans, H.J.; Woodward, B. Effects of feed-borne Fusarium mycotoxins on hematology and immunology of laying hens. Poult. Sci. 2005, 84, 1841-1850. [CrossRef]

97. Chattopadhyay, P.; Upadhyay, A.; Agnihotri, A.; Karmakar, S.; Ghoyary, D.; Veer, V. Original Article Comparative Hematoxicity of Fusirium Mycotoxin in Experimental Sprague-Dawley Rats. Toxicol. Int. 2013, 25-30. [CrossRef] [PubMed]

98. Al-Nedawi, A.M. Reference hematology for commercial Ross 308 broilers. Online Jounrnal Vet. Res. 2018, 22, 566-570. [CrossRef]

99. Meluzzi, A.; Primiceri, G.; Giordani, R.; Fabris, G. Determination of blood constituents reference values in broilers. Poult. Sci. 1992, 71, 337-345. [CrossRef]

100. Talebi, A.; Asri-Rezaei, S.; Rozeh-Chai, R.; Sahraei, R. Comparative studies on haematological values of broiler strains (ross, cobb, arbor-acres and arian). Int. J. Poult. Sci. 2005, 4, 573-579. [CrossRef]

101. Pestka, J.J.; Zhou, H.R.; Moon, Y.; Chung, Y.J. Cellular and molecular mechanisms for immune modulation by deoxynivalenol and other trichothecenes: Unraveling a paradox. Toxicol. Lett. 2004, 153, 61-73. [CrossRef]

102. Lucke, A.; Böhm, J.; Zebeli, Q.; Metzler-Zebeli, B.U. Dietary deoxynivalenol and oral lipopolysaccharide challenge differently affect intestinal innate immune response and barrier function in broiler chickens. J. Anim. Sci. 2018, 96, 5134-5143. [CrossRef] [PubMed]

103. Grenier, B.; Dohnal, I.; Shanmugasundaram, R.; Eicher, S.D.; Selvaraj, R.K.; Schatzmayr, G.; Applegate, T.J. Susceptibility of broiler chickens to coccidiosis when fed subclinical doses of deoxynivalenol and fumonisins-special emphasis on the immunological response and themycotoxin interaction. Toxins 2016, 8, 231. [CrossRef]

104. Li, Z.; Yang, Z.B.; Yang, W.R.; Wang, S.J.; Jiang, S.Z.; Wu, Y.B. Effects of feed-borne Fusarium mycotoxins with or without yeast cell wall adsorbent on organ weight, serum biochemistry, and immunological parameters of broiler chickens. Poult. Sci. 2012, 91, 2487-2495. [CrossRef]

105. Girgis, G.N.; Sharif, S.; Barta, J.R.; Boermans, H.J.; Smith, T.K. Immunomodulatory effects of feed-borne Fusarium mycotoxins in chickens infected with coccidia. Exp. Biol. Med. 2008, 233, 1411-1420. [CrossRef] [PubMed]

106. Ghareeb, K.; Awad, W.A.; Soodoi, C.; Sasgary, S.; Strasser, A.; Böhm, J. Effects of Feed Contaminant Deoxynivalenol on Plasma Cytokines and mRNA Expression of Immune Genes in the Intestine of Broiler Chickens. PLoS ONE 2013, 8, 1-7. [CrossRef] [PubMed]

107. Pestka, J.J. Deoxynivalenol-Induced Proinflammatory Gene Expression: Mechanisms and Pathological Sequelae. Toxins. 2010, 2, 1300-1317. [CrossRef]

108. Zhou, H.R.; He, K.; Landgraf, J.; Pan, X.; Pestka, J.J. Direct activation of ribosome-associated double-stranded rna-dependent protein kinase (PKR) by deoxynivalenol, anisomycin and ricin: A new model for ribotoxic stress response induction. Toxins 2014, 6, 3406-3425. [CrossRef] [PubMed]

109. Pestka, J.J. Deoxynivalenol: Toxicity, mechanisms and animal health risks. Anim. Feed Sci. Technol. 2007, 137, 283-298. [CrossRef]

110. Bondy, G.S.; Pestka, J.J. Immunomodulation by fungal toxins. J. Toxicol. Environ. Heal. Part B Crit. Rev. 2000, 3, 109-143. [CrossRef] 
111. Pestka, J.J. Mechanisms of deoxynivalenol-induced gene expression and apoptosis. Food Additives and Contaminants. Food Addit. Contam. 2008, 25, 1128-1140. [CrossRef]

112. Ueno, Y. Toxicological features of T-2 toxin and related trichothecenes. Fundam. Appl. Toxicol. 1984, 4, S124-S132. [CrossRef]

113. Pestka, J.J.; Yan, D.; King, L.E. Flow cytometric analysis of the effects of in vitro exposure to vomitoxin (deoxynivalenol) on apoptosis in murine T, B and IgA+ cells. Food Chem Toxicol. 1994, 32, 1125-1136. [CrossRef]

114. Sharma, R.P. Immunotoxicity of Mycotoxins. J. Dairy Sci. 1993, 76, 892-897. [CrossRef]

115. Ren, Z.; Wang, Y.; Deng, H.; Deng, Y.; Deng, J.; Zuo, Z.; Wang, Y.; Peng, X.; Cui, H.; Shen, L. Deoxynivalenol induces apoptosis in chicken splenic lymphocytes via the reactive oxygen species-mediated mitochondrial pathway. Environ. Toxicol. Pharmacol. 2015, 39, 339-346. [CrossRef]

116. Yan, D.; Zhou, H.R.; Brooks, K.H.; Pestka, J.J. Potential role of IL-5 and IL-6 in enhanced IgA secretion by Peyer's patch cells isolated from mice acutely exposed to vomitoxin. Toxicology 1997, 122, 145-158. [CrossRef]

117. Zhou, H.R.; Yan, D.; Pestka, J.J. Differential cytokine mRNA expression in mice after oval exposure to the trichothecene vomitoxin (Deoxynivalenol): Dose response and time course. Toxicol. Appl. Pharmacol. 1997, 144, 294-305. [CrossRef] [PubMed]

118. Tachibana, T.; Kodama, T.; Yamane, S.; Makino, R.; Khan, S.I.; Cline, M.A. Possible role of central interleukins on the anorexigenic effect of lipopolysaccharide in chicks. Br. Poult. Sci. 2017, 58, 305-311. [CrossRef] [PubMed]

119. Li, D.; Ye, Y.; Lin, S.; Deng, L.; Fan, X.; Zhang, Y.; Deng, X.; Li, Y.; Yan, H.; Ma, Y. Evaluation of deoxynivalenol-induced toxic effects on DF-1 cells in vitro: Cell-cycle arrest, oxidative stress, and apoptosis. Environ. Toxicol. Pharmacol. 2014, 37, 141-149. [CrossRef] [PubMed]

120. Borutova, R.; Faix, S.; Placha, I.; Gresakova, L.; Cobanova, K.; Leng, L. Effects of deoxynivalenol and zearalenone on oxidative stress and blood phagocytic activity in broilers. Arch. Anim. Nutr. 2008, 62, 303-312. [CrossRef] [PubMed]

121. Frankič, T.; Pajk, T.; Rezar, V.; Levart, A.; Salobir, J. The role of dietary nucleotides in reduction of DNA damage induced by T-2 toxin and deoxynivalenol in chicken leukocytes. Food Chem. Toxicol. 2006, 44, 1838-1844. [CrossRef]

122. Awad, W.A.; Ghareeb, K.; Dadak, A.; Gille, L.; Staniek, K.; Hess, M.; Böhm, J. Genotoxic effects of deoxynivalenol in broiler chickens fed low-protein feeds. Poult. Sci. 2012, 91, 550-555. [CrossRef]

123. de Souza, M.; Baptista, A.A.S.; Valdiviezo, M.J.J.; Justino, L.; Menck-Costa, M.F.; Ferraz, C.R.; da Gloria, E.M.; Verri, W.A.; Bracarense, A.P.F.R.L. Lactobacillus spp. reduces morphological changes and oxidative stress induced by deoxynivalenol on the intestine and liver of broilers. Toxicon 2020, 185, 203-212. [CrossRef]

124. Swamy, H.V.L.N.; Smith, T.K.; Karrow, N.A.; Boermans, H.J. Effects of feeding blends of grains naturally contaminated with Fusarium mycotoxins on brain regional neurochemistry of starter pigs and broiler chickens. J. Anim. Sci. 2004, 82, 2131-2139. [CrossRef]

125. Harwell, B. Biochemistry of oxidative stress. Biochem. Soc. Trans. 2007, 35, 1147-1150. [CrossRef]

126. Payros, D.; Alassane-Kpembi, I.; Pierron, A.; Loiseau, N.; Pinton, P.; Oswald, I.P. Toxicology of deoxynivalenol and its acetylated and modified forms. Arch. Toxicol. 2016, 90, 2931-2957. [CrossRef] [PubMed]

127. Onbaşilar, E.E.; Aksoy, F.T. Stress parameters and immune response of layers under different cage floor and density conditions. Livest. Prod. Sci. 2005, 95, 255-263. [CrossRef]

128. Gross, W.B.; Siegel, H.S. Evaluation of the heterophil/lymphocyte ratio as a measure of stress in chickens. Avian Dis. 1983, 27, 972-979. [CrossRef] [PubMed]

129. Islam, Z.; Pestka, J.J. Role of IL-1 $\beta$ in endotoxin potentiation of deoxynivalenol-induced corticosterone response and leukocyte apoptosis in mice. Toxicol. Sci. 2003, 74, 93-102. [CrossRef] [PubMed]

130. Campo, J.L.; Gil, M.G.; Dávila, S.G.; Muñoz, I. Influence of perches and footpad dermatitis on tonic immobility and heterophil to lymphocyte ratio of chickens. Poult. Sci. 2005, 84, 1004-1009. [CrossRef] 